\section{Kastamonu Eğitim Dergisi Kastamonu Education Journal}

Mart 2019 Cilt:27 Sayı:2

kefdergi.kastamonu.edu.tr
Başvuru Tarihi/Received: 03.04.2018

Kabul Tarihi/Accepted: 29.08.2018

DOI: $10.24106 /$ kefdergi.2933

\title{
Tarih Öğretimi ve Coğrafya
}

\section{Geographical Utilization in History Teaching}

\author{
Pelin İskender KILIÇ⿻1
}

\section{Öz}

Gerek lise tarih ders programlarında gerekse sosyal bilgiler ders programı kapsamı içinde yer alan tarih konularında özel amaçlarının gerçekleştirilmesi için çeşitli yöntem, teknik ve stratejiler kullanılmaktadır. Burada amaç tarih konularının kalıcı ve etkili bir şekilde öğrenilmesini sağlamaktır. Sınıf ortamında öğrencilerin anlama, algılama, eleştirel düşünme ve kazanım oranları ne kadar yüksek olursa, öğrenme o derece etkili olur. Tarihe yardımcı bilim dallarından biri olan coğrafya, tarihin tanımından da anlaşılacağı üzere tarih biliminin önemli bir unsuru ve onu somut hale getiren bir bilim dalıdır. Bir tarihî olay, her zaman bir mekân üzerinde meydana gelir ve bu mekânın özellikleri tarihî olayı az ya da çok etkiler. Bu nedenle tarihî olayın meydana geldiği coğrafyayı tanımadan, olayı nesnel bir şekilde anlamamız mümkün olmayacaktır. Dolayısıyla Annales Okulu'nun yaptı̆ı̆ gibi interdisipliner bir yaklaşımla, bütünsel ve etkili bir tarih öğretimi/öğrenimi sağlanmış olacaktır. Bundan hareketle nitel araştrrma yöntemlerinden biri olan doküman incelemesi yöntemi ile tespit edilen yazılı materyaller analiz edilerek, gerek tarih öğretiminde coğrafyanın yeri gerekse bu iki bilim dalının birbirlerine olan katkıları, kullanılan yöntemler, örnekler ve kaynaklar bazında ortaya konulmaya çalışı Imıştr.

Anahtar Kelimeler: Tarih, tarih öğretimi, coğrafya, tarihsel mekânı algılama becerisi.

\section{Abstract}

A variety of methods, techniques and strategies are used in high school history curricula or in the subjects of social studies curriculum to achieve special purposes. The aim here is to ensure that history topics are taught permanently and effectively. The higher the students' understanding, perception, critical thinking and achievement rates in the classroom environment, the more effective is learning. The aim here is to ensure that history topics are taught permanently and effectively. The higher the students' understanding, perception, critical thinking and achievement rates in the classroom environment, the more effective is learning. Geography, one of the branches of science, as understood from the definition of history is an important element of history science and makes it concrete. A historical event always takes place on a space, and the characteristics of this space affect the historical event more or less. For this reason, without knowing the geography where the historical event has taken place, we will not be able to objectively understand the event. Thus, as with the Annales School, an interdisciplinary approach will provide a holistic and effective history teaching / learning. One of the qualitative research methods, the written materials determined by the method of document analysis were analyzed and the place of geography in history teaching and the contributions of these two sciences to each other were tried to be revealed.

Keywords: History, history teaching, geography, historical location perception skill.

1. Ondokuz Mayıs Üniversitesi, Eğitim Fakültesi, Samsun, Türkiye; https://orcid.org/0000-0001-8755-5989 Attf / Citation: Kılıç, P. I. (2019). Tarih Öğretimi ve Coğrafya. Kastamonu Education Journal, 27(2), 869-883 doi:10.24106/kefdergi.3065 


\section{Extended Summary}

The interdisciplinary approach is used at every stage of education. Nowadays, teaching programs are prepared with an interdisciplinary approach. Particularly, interdisiplinary arrangements in the field of history education in the direction of holistic understanding are both important and necessary. Because, while history matters are explained, it is benefited from many disciplines such as geography, sociology, economics, philosophy, religion, art and so on. If history is to be told without being integrated with these branches of science, the realization of permanent learning and understanding of the logic of the events will be very difficult.

While the student is preparing social life by the lesson of Life Science in Primary Education, from the secondary school, the subject of history and geography is emphasized by history lessons. The ability to perceive the space within the achievements of high school history lessons are gained students by geography branches of assistant science. History can not be taught without knowing the geographical location of the event and its properties. A historical event taken place in the past has been made more concrete with maps, museums, site visits and various visualizations tecniques. In history lessons, the most frequently used material is the history maps. When using maps, only place information is given. But that's not enough. Today, many methods, techniques and approaches (Lecture method, question-answer method, discussion method, trip-observation method, case method, brain based learning, multiple intelligence theory, problem solving method etc.) are utilized in history teaching education. The most important factors in benefiting from these are the nature of the subjects to be taught and the selection of them according to the student and teaching environment. While the topic benefits from a variety of methods, techniques and strategies, it is possible to utilize all relevant aspects of the geography as relevant.

Every historical event takes place in a certain geographical location. During the formation of historical events, the climate, the shape of the earth, geographical factors are influential. Knowing these factors makes a great contribution to the elucidation of all aspects of the historical event. In this sense, history and geography are like brothers. Many civilizations that are included in the subjects of history are expressed by geographical features and concepts. For example, the statement of the Central Asia Steppe Civilization emphasizes both the position and the impact of climate on civilization. Steppe societies ruled by the terrestrial prime become more warrior and fighting societies in the history. Likewise, the people of the mountainous regions are also fighters and warriors as the Balkan and Caucasian societies. Societies living in fertile land along the river and in the ovaries are generally agricultural communities and peaceful. Phrygians, Lydians are a good example. The civilizations built on the seaside generally developed in maritime trade and colonialism such as Aegean civilizations and Mediterranean civilizations. Therefore, when a historian is describing a historical event, he must always keep the geography in which the event passes.

In the same way, a scientist interested in geography, especially in human geography or population geography, should make use of history if he wants to put a solid ground on his field. For example, it is extremely important to know the history of the region in population and migration events. Knowing the historical background of the region in declining or increasing population will help to understand and explain many things. The impact of historical epidemics, wars, migrations, natural disasters and similar positive or negative developments on human geography is inevitable.

The history can be used to determine the meaning of geographical place names and where they come from. For example, when the Oghuz comes to Anatolia, we can understand from the names given to the villages and the towns by which way they followed the west. In many parts of Anatolia, it is possible to see names such as Kayı, Oguz, Kınık, Avşar, Pecenek, Çepni, Bayındır and Iğdır. The work called Geography Warfare is emphasized that geography is a strategic information for the political and military practices in history. According to this, the state uses the geography to organize and to regulate the territories in order to better supervise and organize the people under its sovereignty. Cartography also originated in the early years due to wars and occupations as military purposes (Lacoste, 1998, 12-13).

Many of the primary sources used in history teaching can also be used in geography teaching, which is also a social and human science. We can obtain sources of livelihoods, which plants and animals are raised, underground and above-ground sources, and similar information, from first-hand sources such as şer'iye registers, title deed books, tax books, demographics books. Population data is very important to understand the demographic, social and economic structure of cities and towns. Each state determines the politics to follow and develops policy in this direction. It also identifies the existing economic and human resources in the regions where it takes measures, if necessary. States take into account the size of their geography, the structure and distribution of the population, the population potential of neighboring states and cultural structures. They develop specific population policies that can be summarized in terms of the size and structural distribution of the population and the necessary mechanisms for achieving these targets (Ipek, 2006, 347). For this reason, population books are important. In salnames, there are events effecting people in the region such as floods, famines, droughts, earthquakes, fires, etc., the effects of them and the precautions taken. In addition, the region's livelihoods, earth forms, agricultural products, animal husbandry are also mentioned. These are very valuable for scientists working urban geography, economic geography, historical geography, social and cultural geography, and political geography. Tournaments are extremely important travel notes in terms of keeping the political, administrative, economic, social and cultural features of a region or city in line with the observations of the travelers and keeping light a turn. As it is based on the observations of the people, it is possible to reach important information on almost any topic related to turning when it is passed through a critical criticism. It is particularly striking in terms of completing the gaps in cases where some primary sources are missing or not at all. Because it is possible to find some information on travels that are not included in the official sources of social and cultural life. It also contains important information for the Şer'iyye record, human geography, economic geography and local geography. Şer'iyye registers are the primary sources of territorial sherd being held chronologically in courts. It is possible to get a lot of information such as the economic and social effects of natural disasters like floods, fire and earthquakes in the region, administrative structure of the region, ethnic and religious structure, occupational and social status, the tax paid, what animals and products are grown, and so on.

| Kastamonu Eğitim Dergisi, 27(2), 2019| 


\section{Giriş}

Tarihin birçok tanımı yapılmaktadır. Ancak en çok kabul göreni "Tarih, geçmişte yaşamış olan insan topluluklarının yaşayışlarını, siyasî, kültür ve uygarlık alanında meydana getirmiş olduğu gelişmeleri, yer ve zaman göstererek sebep-sonuç ilişkisi içinde belgelere dayalı olarak objektif bir biçimde incelemeye çalışan sosyal bir bilim dalıdır" şeklindedir (Bkz. Togan, 1969: 1-2; Kütükoğlu, 1990: 2; Kodaman, 1997: 1; Özçelik, 2001: 17-18; Dilek, 2002; Carr, 2005).

Tanımdan da anlaşılacağı üzere tarih bilimi, çok geniş bir çalışma alanına sahiptir. Fakat bu geniş alan içerisinde belirli sınırları mevcuttur. Tarih, geçmişte yaşanmış olayların tespitidir. Günümüz olayları ve gelişmeleri siyaset biliminin, sosyolojinin veya daha farklı bilim dallarının konusu olabilir. Ancak tarihin konusu değildir. Yine tek bir insan tarihin konusu değildir. Tek bir insan psikolojinin, biyolojinin vb. bilimlerin konusu olabilir. Tarihin konusu insan toplulukları, onların faaliyetleri ve kurmuş oldukları devletlerin tarihleridir. Biyografisi incelenen kişiler, toplumlara yön vermiş veya bir devletin tarihinde etkili olmuş kişilerdir.

Hangi tanıma bakılırsa bakıısın, tarih biliminde genelde değişmeyen üç öğe bulunmaktadır. Bunlardan birisi olmazsa olayın tarih olmayacağı vurgulanmaktadır. Bu üç öğe: Zaman, mekân ve toplumdur. Bundan dolayı geniş bir çalışma alanına sahip tarih biliminde, kolaylık sağlamak amacıyla zamana, mekâna ve konuya göre sınıflandırma yoluna gidilmektedir.

Zamana göre sınıflandırma yapılırken, ana hatları ile tarih öncesi ve tarih devirleri olarak iki ana kısma ayrılır. Burada esas alınan yazının icadıdır. Yazıdan önceki devirler, insanoğlunun taş ya da madeni işleyip kullanmasına göre alt gruplara ayrılmıştır. Buna göre Tarih öncesi devirler, taş devri ve maden devri olarak ikiye ayrılır. Bunların da alt grupları mevcuttur. Bu devirler incelenirken, tarih bilimi daha çok arkeolojiden yararlanır. Tarih devirleri ise yazının bulunmasından sonraki devirlerdir. Toplumdan topluma önem verdikleri olaya göre değişiklik göstermektedir. Türkiye'de Avrupa'da kabul görmüş olan bir bölünme esas alınmıştır. Buna göre yazının icadından (M.Ö. 3500) Batı Roma İmparatorluğu'nun yıkılmasına (476) kadar İlkçağ (Eskiçağ), Batı Roma İmparatorluğu'nun yıkılmasından İstanbul'un fethine (1453) kadar Orta Çağ, İstanbul'un fethinden Fransız İhtilali'ne (1789) kadar Yeni Çağ, Fransız İhtilali'nden günümüze kadar Yakın Çağ olarak adlandırılmıştır. Ancak bu tasnifi, Türk tarihine uygun olmadığı gerekçesiyle Nihal Atsız, ibrahim Kafesoğlu, Zeki Velidi Togan gibi bazı Türk tarihçiler kabul etmemektedir (Atsız, 1997: 20-21; Kafesoğlu, 1964: 4-7; Togan, 1985: 26). Bundan dolayı Türk tarihi genellikle zaman olarak İslam Öncesi Türk Tarihi ve Türk-İslam Devletleri Tarihi şeklinde sınıflandırılmıştır.

Mekâna göre sınıflamada ise araştıılan konular, bir coğrafî alan ile sınırlandırılır. Orta Asya Türk Tarihi, Anadolu Tarihi, Mezopotamya Tarihi, Avrupa Tarihi, Kuzey Afrika Tarihi vb... Mekâna göre sınıflandırma tarih konularının araştrııması ve anlatımında en çok başvurulan unsurdur. Sadece uygarlıkları sınıflandırırken veya bölge tarihini anlatırken değil savaşlarda (Kosova Savaşı, Talas Savaşı, Miryokefalon Savaşı, Pasinler Savaşı vb.), anlaşmalarda (Ankara Anlaşması, Edirne-Segedin Anlaşması, Mondoros Ateşkes Anlaşması, Lozan Antlaşması vb.), devlet isimlerinde (Harzemşahlar, Gazneliler vb.) coğrafî mekân ifade edilmiştir.

Konularına göre tarih tasnifi ise toplumların bilinen en eski zamanlarından günümüze kadar geçirmiş oldukları her türlü gelişme ve değişimlerdir. Siyasî tarih, sanat tarihi, yönetim şekli, din ve inanış, toplum yapısı, askerî yapı vb.

Tarih biliminin metodoloji olarak diğer sosyal bilimlerden farkı, her olayın kendine özgü olması, deney ve gözleminin yapılamamasıdır. Geçmişte meydana gelmiş olan olay ve gelişmeleri, belgelere dayalı olarak objektif bir şekilde tespit edip ortaya koyar. Tarih, günümüzde meydana gelen olayları değil üzerinden belli bir zaman geçmiş olan olay ve gelişmeleri konu alır. Araştıılan bu olay ve gelişmeler, toplum ve devlet üzerinde etkili olmalıdır. Her ne kadar tarihin konusu geçmişteki olaylar ise de tarihi bilmek, geleceğe yön vermede oldukça etkilidir. Hayatın her alanında tarih vardır. Tarihin diğer bilimlerde olduğu gibi kesin bir kanun ve kuralı yoktur. Yani hiç bir zaman 100.000 kişilik bir ordu 50.000 kişilik bir orduyu yener diyemeyiz. Tarihte kendisinin iki-üç kat büyüklüğündeki orduları yenilgiye uğratan pek çok savaş olmuştur. Örneğin; Malazgirt Savaşı'nda Selçuklu ordusunun 14.000 kişiden oluşurken, Doğu Roma (Bizans) ordusunun 300.000 kişi olduğu belirtilir (Cahen, 1972: 89-90).

Tarih biliminde, diğer tüm sosyal bilimlerde olduğu gibi farklı yaklaşımlar (paradigma) vardır. Annales Okulu'nda tarih yazıcılığı, siyasal tarihten çok sosyal ve ekonomik kaynakları esas alır. Annales'in yeni bir tarih anlayışı hedefi ile yola çıkmasının en önemli sebebi aslında tarihi, tüm sosyal olgular ısı̆ı̆ında incelemek arzusu ve gerekliliğidir (Yeğen, 2016: 26). Özellikle de XX. yüzyılın başlarından itibaren sosyal ağılıklıdır. Bu yaklaşımın içerisinde Fernand Braudel ile birlikte tarih yazımına yeni bir bakış getirilmiştir (Ayan, 2011: 76). Braudel, tarihî olayları doğal, yapısal ve sosyal koşulların birlikte belirlediğinin üzerinde durur. Yani tarihî olayların meydana gelmesinde coğrafyanın da etkisi vardır. Aynı şekil- 
de onun devamında gelen yine bu okulun temsilcilerinden ve aynı zamanda çağımızın ünlü sosyologlarından biri olan Immanuel Wallerstein de coğrafya paradigmasını temel alarak ulusal-siyasî tarih yerine bölgesel tarihi esas alır. Onlara göre, dağlı-ovalı, deniz toplumu-kara toplumu, doğu-bat gibi coğrafî farklılıklar tarihin gelişiminde etkilidir. Bu açıdan bakıldığında tarih ve coğrafya birbirinden ayrılamaz bir bütündür.

Bu makalede, lise tarih programlarında yer alan konuların öğretilmesinde ve öğrenilmesinde, tarihe yardımcı bilim dallarından biri olan coğrafyadan nasıl yararlanılabileceğinin yanı sıra coğrafya derslerinin öğretilmesinde de tarih biliminde yararlanan birinci elden kaynaklardan nasıl yararlanılabileceği konusu ele alınmıştır.

\section{Yöntem}

Her tarihî olay belli bir coğrafî mekânda meydana gelir. Tarihî olayların oluşumu esnasında iklim, yeryüzü şekilleri, ekonomik faaliyetler, konum vb. coğrafî faktörler etkili olabilmektedir. Bu faktörlerin bilinmesi tarihî olayın tüm yönlerinin aydınlatılmasına büyük ölçüde katkı sağlamaktadır. Bu çalışmada araştrma verileri, nitel araştırma yöntemlerinden biri olan ve özellikle tarihçilerin, antropologların ve sosyologların araştırmalarında sıklıkla başvurdukları doküman incelemesi ile toplanmıştır. Doküman incelemesi, araştırıması hedeflenen olgu ya da olgular hakkında bilgi içeren yazıı materyallerin analizini kapsamaktadır. Doküman incelemesi, bir araştırma problemi hakkında belirli zaman dilimi içerisinde üretilen dokümanlar ya da ilgili konuda birden fazla kaynak tarafindan ve değişik aralıklarla üretilmiş dokümanların geniş bir zaman dilimine dayalı analizini olanaklı kılmaktadır (Yıldııı ve Şimşek, 2005: 187-188). Tarih ders programlarında yer alan konularda geçen coğrafî kavram ve terimlerin, tarihin öğretilip öğrenililmesindeki rolü örneklerle ortaya konulmaya çalışılmıştır.

\section{Bulgular ve Yorumlar}

Oldukça geniş bir konu olan tarih-coğrafya ilişkisi, en etkili görülen dört alt problem doğrultusunda ele alınmıştır. Bu bağlamda; "Tarih Öğretiminin Amaçları, Günümüzde Tarih Öğretiminde Egemen Olan Yöntemler ve Yaklaşımlar” alt başlı̆ıında tarih öğretiminde en sık kullanılan ve/veya coğrafyadan yararlanılarak öğrencide daha kalıcı öğrenmelerin sağlanabileceği düşünülen örneklerin verilebileceği yöntem ve yaklaşımlar ele alınmaya gayret edilmiştir. Tarih öğretiminin amaçları doğrultusunda coğrafyadan örnekler verilerek bu konu açıklanmaya çalışılmıştır.

İkinci alt problem, "Tarih ve Coğrafya Disiplinleri Arasında Çalışma Alanları Bağlamındaki Paralellikler" başlığı altında ele alınmıştır. Burada tarih biliminin en sık yararlandığı bilim dalı olan coğrafyanın mekân, tabi şartların toplumlar üzerindeki etkileri vb. yönlerden tarihe olan katkıları irdelenirken, diğer taraftan tarih biliminin de geçmişteki insan topluluklarının faaliyetleri, özellikle beşerî ve nüfus coğrafyası başta olmak üzere coğrafya bilimine katkıları ve çalışma alanları bağlamındaki paralellikleri ortaya konulmaya çalışılmıştr.

Üçüncü alt problem "Tarih Öğretiminde Kullanılan Birinci Elden Kaynakların Coğrafya Öğretiminde Kullanımı” şeklinde ele alınmıştır. Burada amaç, çalışma alanları birbirine paralellik gösteren coğrafya bilminin bazı alt dallarında, tarih öğretimi ve tarih biliminde kullanılan birinci elden kaynakların coğrafya öğretimi ve coğrafya biliminde de kullanıldığını /kullanılabileceğini ortaya koymaktır.

Dördüncü alt problemde "Tarihî Süreç İçinde Toplumların Davranışlarının Açıklanmasında ve Anlaşıımasında Coğrafî Unsurların Etkisi" başlığıyla coğrafí unsurların tarihî süreçte toplumların davranışlarının açıklanmasında ve anlaşılmasında ne derece etkili olduğu, örneklerle anlatılmaya çalışılmıştır.

\section{Tarih Öğretiminin Amaçları, Günümüzde Tarih Öğretiminde Egemen Olan Yöntemler ve Yaklaşımlar}

Sosyal bir bilim dalı olan tarih, geçmişte meydana gelmiş olan olayları bir metot çerçevesinde belgelere dayalı olarak gerçeklere yakın bir şekilde inceleyip, araştrarak ortaya koymaya çalışır. Tarih bilimi, her ne kadar kendine özgü farklı metodolojisi olsa da birçok bilim dalından yararlanan disiplinler arası özelliğe sahip bir bilim dalıdır. Olayları daha doğru ve tarafsız görebilmek, diğer bilim dallarının tarihe yapmış olduğu katkılar sonucunda olanaklı hale gelmektedir. Ancak bu bilim dalları da kendi metodolojisi ve bakış açısıyla tarih bilimine yaklaşır. Durum böyle olunca tarih biliminin, diğer bilim dallarının çeşitli amaçları doğrultusunda kullanıldığı görülmektedir. Siyaset bilimi, din ve ahlak, sanat, sosyoloji ve benzeri bilim dalları tarihe farklı misyonlar yükler. Özellikle siyaset bilimi, farklı dönemlerde tarih öğretimine farklı görevler yüklemiştir. Tarih ve tarih dersleri, devletlerin ideolojilerini gelecek nesillere aktarmada yararlanılan en önemli unsur olmuştur. Örneğin Birinci Dünya Savaşı'ndan günümüze kadar meydana gelen gelişmelerin tarih ders kitaplarına aktarımında önemli değişimler meydana gelmiştir. Hatta ülkemizde Tek Parti döneminde, Demokrat Parti döneminde, 
1960 hükümet darbesi sonrasında, 1980 hükümet darbesi sonrasında ve günümüze kadar tarih ders programı ve kitaplarında önemli değişiklikler meydana gelmiştir. Bundan hareketle tarih öğretiminin amaçlarından ilki, gelenekçi bir yaklaşım doğrultusunda, vatandaşlık ve kimlik aktarımıdır. Bu yaklaşımla öğrencilere geçmişin bilgisi öğretilerek, tarihini, toplumunu, değerlerini, kültürünü tanıyan ve benimseyen iyi vatandaşların yetiştirilmesi amaçlanmaktadır (Demircioğlu, 2006). Yani hedef, öğrencilerde millî kimliğin oluşturulması, millî duyarlııı̆ın ve vatandaşlık bilincinin geliştirilmesidir. Aynı zamanda öğrencilerde vatan, millet, devlet bilinci geliştirilerek, hak ve sorumluluklar da öğretilir. Bu bağlamda tarih dersine giren bir öğretmenin yakın ve uzak amaçların olması ve bu doğrultuda dersi planlaması gerekir. Yakın amacı, o günkü dersinin konusunu en iyi ve öğrencinin kavrayacağı şekilde planlamasıdır. Uzak amacı ise vatan, millet, devlet sevgisi olan ve iyi bir vatandaşta olması gereken hak ve sorumlulukları bilen bireyler yetiştirmektir. Dolayısıyla değerler eğitimi de bu anlamda son derece önemlidir. Öğrencilere, tarih dersleri aracılığı ile kültürel ve toplumsal değerler ve bunların gelişimini öğretmek mümkündür (Demircioğlu ve Tokdemir, 2008: 69-88).

Günümüz tarih öğretim programlarına bakıldığında, tarih öğretiminden yaratıcı düşünme, problem çözme, eleştirel düşünme, bilgi teknolojilerini kullanma, Türkçeyi doğru ve etkili kullanma, iletişim kurma, araştırma ve sorgulama gibi temel becerilerin kazandırılması da amaçlanmaktadır. Yine aynı şekilde tarihsel düşünme becerileri olan kronolojik düşünme, tarihsel kavrama, tarihsel analiz ve yorum, tarihsel sorun analizi ve karar verme, tarihsel sorgulamaya dayalı araştırma gibi becerilerin kazandırılması da amaçlar arasındadır. Böylece öğrencilere bilimsel bakış açısı ve üst düzey düşünme becerileri ve niteliklerinin kazandırılması hedeflenmektedir. Tarih öğretimini, amaçlar düzeyinde üçe ayırmak mümkündür. Bunlar öğrencinin kişisel gelişimi açısından, kültürel mirasın aktarımı açısından ve vatandaşlık eğitimi açısından tarih öğretimi olarak belirtilebilir (Bkz. Dilek, 2002). Eğitimcinin görevi, bilginin öğrenciye nasıl verilmesi gerektiğini iyi değerlendirmektir. Hiçbir ders için tek bir yöntem kullanılamaz. Öğretmen kendi kişisel çabaları ve duyarlılı̆̆ıla sınıfina ve dersteki konusuna en uygun yöntemi veya yöntemleri seçerek ve yine sınıftan aldığı sinyallerle değişiklikler yapabilmelidir. Önemli olan öğretmenin konunun en iyi öğretimini sağlayacak yöntem zenginliğine gitmesidir (Küçükahmet, 2001: 73).

Günümüzde tarih öğretiminde, birçok yöntem ve yaklaşımlardan yararlanıldığı görülmektedir. Bunlardan yararlanırken en önemli unsur, başta öğretilecek konuların özelliğine göre daha sonra ise öğrenci ve öğretim ortamına göre bunların seçilmesidir. Her derste mutlaka her teknik kullanılacak diye bir şey söz konusu olamaz. Tarih derslerinde genel itibarıyla en çok kullanılan yöntem, teknik ve yaklaşımları ve bunların özelliklerini coğrafya örnekli şu şekilde belirtebiliriz:

Anlatım (Takrir, Sunuş) Yöntemi: Sosyal bir bilim dalı olan tarih, genel olarak öğrenciler tarafindan konuların okunup ezberlenerek akılda tutulması şeklinde algılanmaktadır. Oysaki tarihsel olay, tarihin tanımından da anlaşılacağı üzere insan toplulukları tarafindan meydana getirilen, toplum ve devletleri etkileyen olaylardır. Durum böyle olunca tarihte meydana gelen olayların bir nedeni ve bunun getirdiği sonuçları vardır. Hiç bir olay nedensiz ve anlamsız olarak meydana gelmemiştir. $O$ halde tarihte meydana gelen olaylar mantıksı bir şekilde sırf ezberleyerek akılda tutulması gereken olgular değildir. Dolayısıyla günümüzde etkili olan öğrenci merkezli yaklaşımlardır. Anlatım yöntemi, genel olarak öğrenciler pasif konumda oldukları ve sunu sırasında soru sorma ve düşüncelerini açıklama firsatını fazla bulamadıkları için etkili bir yöntem olarak kabul edilmez. Ancak çok sayıda öğrenciye kısa zamanda bilginin aktarılması, temel kavramların, tanımların, teorilerin öğretilmesi, dinleyenlerin konuyla ilgili organize bir görüş kazanması gibi nedenlerden dolayı hâlâ tarih derslerinde kullanılan etkili yöntemlerden biridir. Fakat bu yöntemin derslerde uzun süre kullanılması öğrenci açısından dersi sıkıcı hale getirebilir ve bunun sonucunda istenilen amaca ulaşılamayabilir. Bundan dolayı bu yöntem, daha çok derse giriş yaparken, bazı kavramlar açıklanırken ya da konu özetlenirken kullanılması halinde daha etkili olacaktır. Bu yöntem kullanılırken öğretmenin bazı görsellikleri anlatımla aynı anda kullanması derste daha etkili öğrenimin sağlanması açısından önemlidir. Burada coğrafya ile desteklemek oldukça önemlidir. Öğrencilerde kavram yanılgılarını önlemek ve kalıcı öğrenmeyi sağlamak amacıyla konuya uygun haritalardan yararlanılabilir. Çünkü haritalar, öğrencilerde mekânı algılama becerisinin gelişmesinde oldukça etkilidir (Bkz. Şengül Bircan ve Safran, 2013: 461-476). Örneğin, ticaret yolları (Kralyolu, Kürk yolu, İpekyolu, Baharat yolu) anlatlırken bunların geçtikleri güzergâhlar, bir harita ile desteklenebilir (Çakmak ve Hamarat, 2016: 424-425). Harita üzerinde Kürk yolunun İpek yoluna kuzeyden paralel bir yol olduğu gösterilerek buranın daha soğuk olduğu için kürk hayvanlarının ve kürklerinin satıldığı bir yol olduğu için ismini buradan aldığının söylenmesi öğrencide daha kalıcı öğrenme sağlayacaktır. Ya da Türklerin ilk görüldüğü yerlerden biri olan Gobi Çölü anlatılırken "Çölde nasıl hayatta kalınabilir?” veya bozkır kültürü anlatılırken "Burası her zaman verimsiz bir arazi midir?" gibi öğrencilerde meydana gelebilecek çöl ve bozkır kavramları ile ilgili olumsuzluklar, buraların görsellikleri ile bu coğrafî bölgelerin her zaman ve her yerinin olumsuz olduğu gibi bir yanılgıyı ortadan kaldırabilir. Aynı şekilde tarih derslerinde çok geçen Hazar Gölü'nün yeri haritada gösterilerek buraya neden deniz denilemeyeceği yine coğrafî bir kavram olan göl ve deniz kavramlarıyla açıklanabilir. 
Soru-Cevap Yöntemi: Genellikle anlatım yöntemi ile birlikte kullanılan bu yöntem, öğretmenin öğrencilere ve öğrencilerin de öğretmene sorduğu soruları içeren ve çift yönlü iletişimin olduğu bir yöntemdir. Soru-cevap aynı zamanda anlatım yöntemini zenginleştiren bir teknik olarak da kullanılır. Sorular, öğrenci bilgisini yoklamak amacıyla değil, onları düşündürmek, önemli noktalara dikkat çekmek ve doğru cevabı öğrencilere buldurmak amacıyla sorulur. Öğrencilerin düşünme, hatırlama, muhakeme, analiz, sentez ve değerlendirme yeteneklerini geliştiren bir yöntemdir. Tarih derslerinde oldukça sık başvurulan bir yöntemdir. Bu yöntem kullanılırken derslerde farklı soru sorma basamaklarından yararlanılabilir. En çok kabul gören Bloom'un bilişsel alanla ilgili alt soru sorma basamağıdır (Arı, 2011:750). Bunlardan bilgi soruları temel bilgileri, kavramları, genellemeleri ve ilkeleri kapsar. Öğrenci kendinden birşey katmaz, bilgiyi olduğu gibi tekrar eder. Maveraü'n-nehir neresidir?, Mezopotamya neresidir?, Bozkır kültürü nedir?, Yarı göçebe nedir? vb. kavram ve olguları anlamaya ve tanımlamaya yönelik sorulardır. Kavrama soruları, öğrencilerin özümsediği ve kendine mal ettiği, kullandığı davranışlardır. Örneğin, tımarlı sipahiler ile yeniçerileri karşılaştırınız. ikili teşkilat ile eyalet arasındaki benzerlikler nelerdir? Gibi. Uygulama soruları, öğrencinin öğrenilen bilgiyi yeni olan durumlara uygulayabilmesidir. Günümüz Türk kültüründe hangi kültürlerin etkisi vardır?, Ülkelerin coğrafi konumlarının politikalarına etkisi nedir? Şeklinde. Analiz soruları, bir sistemin ne gibi öğelerden oluştuğunu, öğeler arasındaki ilişkileri ortaya çıkarmayı içerir. Daha üst düzey zihinsel düşünmeyi gerektirir. Bu çeşit zihinsel etkinlik soyut düşünmeyi gerektirir. Kıbrıs meselesinde izlenen politikaları ve getirdiklerini analiz ediniz. Sözde Ermeni meselesinin çıkmasına neden olan gelişmeleri analiz ediniz. Sentez soruları açık uçlu sorulardır. Bir yenilik, orijinallik, buluş, yaratıcılık gibi özellikler yer alır. Fikirleri uygun sıraya koyma, bir ana fikri yeterli delillerle savunma, bir hipotezi sınamak için yöntem teklif etme gibi davranışlar içerir. Birleşmiş Milletlerin Orta Doğu'da olası bir savaşı engelleyebileceği bir plan öneriniz. Değerlendirme soruları, fikirler arasındaki tutarlıık ya da tutarsızıkları belirleme, mantıksal yargıları bulma, ulaşılan sonuçları yorumlama gibi davranışları içerir. Devletçilik ekonomi politikasının uygulanmasına neden gerek duyuldu? Topluma etkileri neler oldu? Değerlendiriniz. Türklerin savaş taktiklerinden Turan taktiğine baktı̆ımızda, bulundukları coğrafyayı iyi bildikleri sonucunu çıkarabilir miyiz? Değerlendiriniz. Şeklinde olabilir.

Tartışma Yöntemi: "Şayet eğitimin amacı sadece bir konuda veya alanda bilgi sahibi kılmaksa... takrir metodunu kullanmak tartş̧ma metodunu kullanmaktan çok daha iyidir. Yok eğer, eğitimin amacı problem çözümleyecek nitelikte bazı yetenek ve hünerlerin geliştirilmesi ise, o takdirde en yetersiz sınıf tartışması bile bir çok takrirden daha üstündür" B. Bloom.

Bir grubun, bir başkanın yönetimi altında belli bir düzen içerisinde ortak bir konu üzerinde ve belli bir amaca yönelik olarak karşılıklı görüşmeleri şeklinde uygulanan ve öğrenci merkezli bir yöntemdir. Öğrenciler arasında etkileşimi artırmakta, liderlik becerisini geliştirmekte, görüş birliğine ulaşmayı kolaylaştırmakta, çelişkileri uzlaştırmakta, yorumlama becerisini geliştirmekte ve analiz, sentez, değerlendirme gibi üst düzey öğrenmeleri kolaylaştrrmakta etkili bir yöntemdir. Tarih derslerinde en çok kullanılan yöntemlerden biridir. Büyük Grup Tartş̧ması, Küçük Grup Tartşması, Açık oturum, Münazara, Panel, Forum, Sempozyum, Beyin firtınası gibi farklı uygulama teknikleri vardır. Münazara ve beyin firtınası teknikleri tarih derslerinde eskiden beri en sık uygulanan tekniklerdir. Örneğin münazara için Savaş bir akıl oyunu mudur? Yoksa bir güç göstergesi midir? Tartı̧̧ıız. Ya da "Bir tarihi olayın meydana gelmesinde coğrafya mı, ekonomik faktörler mi daha etkilidir?" Tartışınız. Şeklinde olabilir.

Gezi-Gözlem Yöntemi: Bu yöntem, Tarih öğretiminin, sınıf ortamında sözlü anlatımdan alınıp görmenin son derece etkili olduğu amaçlı, planlı bir şekilde okul dışında bir ortama giderek öğrenmenin gerçekleşmesini sağlaması açısından önemlidir. Öğrenciler için öğretim materyallerinin olduğu yere giderek gözlem yapabilme imkânına sahip olmak, olayın gerçekleştiği yeri görmek kalıcı öğrenmelerin sağlanması açısından etkilidir. Aynı zamanda bu öğrencinin okul ortamının tek düzeliğinden uzaklaşmasını sağlayacaktır. Tarihi yerlerde öğrencilerin görerek ve yaşayarak öğrenmelerine imkân tanındığından öğrencilerde analiz, sentez ve değerlendirme becerilerini geliştirecektir. Ancak bu yöntem, hoşça vakit geçirilen basit bir ziyaretten ibaret olmamalıdır. Bunun için en başından itibaren belirli bir plan çerçevesinde hareket edilerek gezinin amacına ulaşmak önemlidir. Gezi öncesinde öğrencilere ne kazandırımak isteniyorsa onunla ilgi ön bir araştırma yaptırılmalıdır. Gezi esnasında ise amaca uygun şekilde sorularla öğrencinin dikkati, götürülmüş olan yere ve bu yerin özelliklerine çekilebilmelidir. Örneğin Ihlara Vadisi'ne götürülen bir öğrenci grubu serbest bırakılarak o yöreyi gezmeleri sağlanırsa hoş bir gezi olmaktan ileri gidemez. Öğrenci çevreye bakar ancak birçok şeyi kaçırarak göremeyebilir. Ancak bu bölge, bir rehber eşliğinde gezilip bazı yerlere dikkat çekilecek olursa yalnızca bakılmaz aynı zamanda özelliği de görülmüş olur. Bu bölge Hıristiyanlı̆ıın ilk yıllarında önemli bir merkezdi. Çünkü Roma döneminde Hıristiyanlık doğmuş ancak ilk zamanlarda devlet tarafindan kabul edilmemişti. Bundan dolayı ilk Hıristiyanlar, Romalılar tarafindan takip ediliyor ve bulunduklarında öldürülüyorlardı. Bundan dolayı saklanarak ilk basit şapeller ve kiliseleri bu vadi içerisine inşa etmişlerdi. Yukarıdan bakıldığında bunlar görülemiyorlardı. Ancak çok yakınına gidildiğinde fark edilebiliyorlardı. illk çağlardan itibaren doğayla tarihin bir arada bulunduğu Ihlara Vadisi bu anlamda çok önemlidir. Öğrencinin 
bunu yerinde görmesi çok daha kalıcı öğrenmenin gerçekleşmesi açısından önemlidir. Bu şekilde sayısız örnek vermek mümkündür. Örneğin Çanakkale cephesi ve İngilizlerin buraya çıkarken coğrafyayı bilmediklerinden dolayı yaptıları hata, savaşın gidişatının değiştirmiştir. Yine aynı şekilde Ankara Savaşı'nı anlatırken Çubuk Ovası, Miryokefalon Savaşı'nı anlatırken Bizans ordusunun Menderes Vadi'sine girmesi ve buranın bir çıkmaz yol olma niteliğinde olması, Sarıkamış harekâtı ve burada alınan yenilginin bu bölge coğrafyası ile olan yakın ilgisi, İnebahtı yenilgisi ve benzeri birçok olay, Gayrimüslim evleri ve müslüman evlerinin bulunduğu çeşitli illerimize yapılan geziler ve buradan çıkan gerek gayrimüslimlerin gerekse müslümanların sosyo-ekonomik, kültürel yapıları ve dünyaya bakışları, müze gezileri ve eserlerin yerinde görülmesi, toplumların sanatları vb. birçok gezi, öğrencilerin tarihi gelişmeleri yerinde görmelerine ve bunların planlı verilmesi sonucu daha kalıcı öğrenme sağlanmasına imkân tanıyacaktır.

Tarih ve coğrafya disiplinleri arasında, bu disiplinlerin öğretiminde izlenen yöntem ve yaklaşımlar bağlamında düşünüldüğünde, yöntemlerin uygulanması anlamında en çok ortak noktanın gezi-gözlem yönteminde olduğu kuşkusuzdur. Tarihi yerlerle öğretim yöntemi, coğrafya derslerinde konuların öğretiminde rahatlıkla uygulanabilir.

Örnek Olay Yöntemi: Öğrenci merkezli olan bu yöntem, buluş yoluyla öğrenme stratejisi için uygun bir yöntemdir. Öğrencinin, problemi aşama aşama analiz ederek çözmesi ve sonuca ulaşmayı sağlaması açısından oldukça etkilidir. Önceki öğrenmelerin transferini sağlar. Örnek olay, yazılı metin biçiminde olabildiği gibi senaryo biçimindeki filimler, gazetelerden, anılardan, çeşitli kitaplardan alınmış parçalar da olabilir. Tarih öğretiminde Anılar, Görgü Tanıklarııın Raporları, Kronolojiler, incelenen dönemde yazılmış gazete ve dergiler, Araştırma Raporları, Dokümanlar, Bilimsel kitaplar, Seyahatnameler, resim ve fotoğraflar kullanılabilir. Ancak bunlar seçilirken bazı kriterlere dikkat etmek gerekir. Örneğin bir olay incelenirken dönemin tek bir gazetesine değil farklı görüşlerdeki gazetelere bakmak daha objektif karar vermede etkili olacaktır. Aynı şekilde olay meydana gelirken kaleme alınan anılar, olayın bitmesinden yıllar sonra hatta olayda adı geçen kişilerden bazıları öldükten sonra kaleme alınan anılara göre daha değerlidir. Yine II. Dünya Savaşı işlenirken, o dönemde çekilmiş bir fotograf ya da çizilmiş bir karikatürden hareketle öğrencilerin dikkatleri, verilmek istenilen konuya çekilerek yorumlamaları istenebilir. Osmanlı Devleti'nde farklı dönemlerde depremler, sel, çekirge istilası, şiddetli kışlar vb. çeşitli doğal afetler meydana gelmiştir. Bunlarla ilgili raporlar, layihalar hazırlanmıştr. Bunlar incelendiğinde olayın boyutu, etkileri, alınan tedbirler vb. birçok bilgi edinmek mümkündür. Bunlardan tarih ve coğrafya derslerinde yararlanılarak, öğrencilerin ilgileri çekilip bilinçlendirilebilir.

Beyin Temelli Öğrenme: Tarih öğretiminin hedeflerinden birisi öğrencilerin "kişilik gelişimi", "sosyalleşme" ve "vatandaşlık eğitimi"ne katkıda bulunmaktır (Dilek, 2002: 52). Bu nedenle son zamanlarda geleneksel tarih öğretiminden farklı olarak derslerde çeşitli öğretim yöntemleri uygulanmaktadır. Tarih öğretiminde kullanılabilecek etkili yöntemlerden birisi de beyin temelli öğretimdir. Beyin de kalp ya da akciğer gibi bir organdır. Her bir organın doğal bir işlevi vardır. Beyinin işi öğrenmektir ve beyin büyük bir öğrenme kapasitesine sahiptir. Kişinin yaşına, milliyetine veya kültürel geçmişine bakmaksızın, her sağlıkı insanın beyni birtakım olağanüstü belirleyici niteliklerle donatımıştır (Caine, 2002: 3). Beynin en etkin biçimde kullanılabilmesi için, içinde birçok etkinliği barındırabilecek beyin temelli öğretim stratejileri uygulanmalıdır. Bunlar: Farklı Disiplinlerden Yararlanılması. Örneğin tarih derslerinde coğrafya, sosyoloji, felsefe, ekonomi vb. disiplinlerle bağlant kurulması; Tematik Öğrenme. Bilgi yığınlarını bir çatı altında toplayarak, ana tema ile ilişkilendirilmesi. Örneğin Kapıkulu ocağının özelliklerinin onun alt sınıfı olan yeniçeri ocağının da özellikleri olduğunun belirtilmesi ya da bozkır uygarlığındaki toplumların ekononomik faaliyetlerinin büyük ölçüde bir birine benzemesi. Konuya Bağlı Ahenkli Düzenleme. Tarih dersinin değişim, süreklilik ve çatşma gibi temel kavramlarla işlenmesi ve son olarak iş birliğine dayalı öğrenme ve yapılacak etkinliklerdir (Demircioğlu, 2007: 39-40). Beyni güçlendiren öğrenim stratejileri uygulanırken Tarih derslerinde sıkça kullanılan kavram ve zihin haritalarının oluşturulması, Balık kılçığı diyagramının kullanılması, benzerlik ve farklıııların ortaya konulması, bu bağlamda karşılaştırma, sınıflama, analojiye yer verilmesi ve farklı sembol ve sistemlerin kullanılması son derece önemlidir. Kavram haritaları, kavramlar arasındaki ilişkiyi grafiksel olarak ortaya koyan bir tekniktir. Zihin haritaları ise insan beyninin potansiyelini geliştirir ve beyin firtınasının organize edilmiş bir yöntemidir. Osmanlı Devleti'nin vergi sistemi, toprak sistemi ya da ordu sistemi ile ilgili kavram haritaları hazırlanabilir. Aynı şekilde Osmanlı Devleti'nin gerileme dönemindeki savaşlar ve anlaşmalar, Osmanlı Devleti'ndeki iç isyanlar, Atatürk IIlkeleri ile ilgili zihin haritaları yaptırılabilir. Balık kılçığı diyagramı olarak ise XVIII. yüzyıl Osmanlı Devleti'ndeki ıslahatçı padişahlar ve özellikleri ya da I. Dünya Savaşı'nın nedenleri hazırlatılabilir. Benzerlikler ve farklılıkların ortaya konulması da tarih öğretiminde konunun özümsenmesi ve anlaşılması bakımından son derece önemlidir. Tarih öğretiminde karşılaştırma oldukça sık yapılır. Örneğin, I. Viyana kuşatması ile II. Viyana kuşatmasını karşılaştırınız, Federasyon ile konfederasyonu karşılaştırını. Sınıflandırma, öğrencilerin konuları kavramasında etkilidir. Örneğin, Osmanlı Devleti'nin genişleme nedenleri nelerdir? Veya Osmanlı Devleti'nin duraklamasının nedenleri nelerdir? Şeklinde sınıflandırmalar yapılabilir. Analoji, iki olgu arasındaki benzerliğe dayanarak bir çıkarımda bulunmaktır. Burada bilinmeyen ya da az bilinen bir olgu daha iyi bilinen benzer bir olguyla açıklanmaya çalışılır. Örneğin, Vezir-i 
azam=Başbakan, Vezirler= Bakanlar, Defterdar=Maliye bakanı gibi.

Çoklu Zekâ Kuramından hareketle sınıfta her türlü zekâ türünde öğrencilerin olabileceği göz önünde bulundurularak ders planlanabilir. Problem çözme yöntemi, Proje çalışması yöntemi, Bireysel çalışma yöntemi, İ̧̧birliğine dayalı öğrenme (Kubaşı öğrenme), Drama, Rol oynama, Altı Şapkalı Düşünme, İstasyon tekniği gibi birçok teknik tarih derslerinde kullanılabilir.

\section{Tarih ve Coğrafya Disiplinleri Arasında Çalışma Alanları Bağlamındaki Paralellikler}

Tarih, eski bir bilim dalıdır. Çünkü insanoğlu geçmişini her zaman merak etmiştir. Zaman içerisinde tarih biliminin yöntemi ve metodolojisinde önemli değişiklikler meydana gelmiştir. Eski dönem tarihçileri genellikle ya gezginler ya da devletin resmî tarihçileridir. Bunlardan gezgin olanlar, gitmiş oldukları yerlerde gördüklerini yazmışlardır. Örneğin Herodot (M.Ö. 490-452), eserinde Yunanlıların ve Yunan olmayanların genel anlamda tarihini vererek, olayları kendi bakış açısıyla anlatmaktadır. Olayları anlatırken mitolojiye de yer vermiştir (Herodotos, 1983). Devletin resmî tarihçileri ise Osmanlı'da ifade edildiği şekliyle vakanüvis yani olayları belli bir kronoloji ile yazan kişilerdir.

Tarihten farklı anlamlar çıkaranlar da olmuştur. Ranke, 1830'larda tarihten ahlak dersleri çıkartan anlayışa karşı çıkarak tarihçinin görevinin yalnızca "Nasılsa öylece göstermek" olduğunu ifade etmiştir (Carr, 2003: 11). Uzunca bir süre bu söz tarihçiler arasında oldukça kabul görmüştür.

Tarih biliminin yararlandığı pek çok bilim dalı vardır. Bu bilim dallarının her biri tarih bilimine önemli katkılar sağlar. Ancak bu bilim dalları içerisinde coğrafyanın ayrı bir yeri vardır. Tarih ve coğrafya kardeş gibidir. Bu iki bilim alanının kardeşliği, zaman ve mekân kavramlarının simetrik oluşundan ileri gelmektedir. Dış dünyadaki nesnelerin yayılımı, mekânı ortaya çıkartmaktadır. Aynı şekilde bu nesnelerin sırası da zamanı ortaya çıkartmaktadır. Zaman ve mekânın birlikte ele alınışı tarih ve coğrafyayı simetrik bilimler haline getirmektedir (Tekeli, 2014: 3-4). Her iki bilim dalı da beşerî bilimler içerisinde yer alır. Coğrafya biliminin konusunun önemli bir kısmı, insan ve mekân arasındaki ilişkiyi incelemektedir. İnsanların tarihe konu olan faaliyetlerinin geçtiği mekânı, coğrafya tarif ve tasvir eder. O coğrafyanın özellikleri, tarihî olayın oluşumunda ve gelişiminde son derece etkilidir (Boehm, Saxe ve Rutherford, 2003: 7). Çünkü bu tabiî şartların yani iklim, çevre ve diğerlerinin insanlar üzerindeki etkisi büyüktür. Şemseddin Sami'nin Kamus'ul Alam adlı eseri bu iki bilimin birbirine olan etkisini ortaya koyması açısından önemlidir. Yazar eserinde, bu iki bilimin birbirinden ayrı düşünülemeyeceğini ve birbirine muhtaç olduklarını vurgulamaktadır (Günüşçü, 2010: 209). Diamond ise tarihin farklı halklar için farklı yönde geliştiğini, bunun nedeninin halkların biyolojik farklııklarından değil farklı coğrafî bölgelerden kaynaklandığını ifade eder (Diamond, 2010: 18).

Annales Okulu'nda da tarih ve bölge ya da zaman ve mekân bir bütün olarak ele alınmıştır (Tekeli, 2014: 4). Çünkü tarihî olayların geçtiği mekânlar ve bu mekânların özellikleri tarihin seyrini derinden etkilemektedir. Dewey, 1924 tarihli raporunda, okullarda tarih ve coğrafya derslerinin birbirini tamamladığını, hatta mümkünse bu derslerin öğrencilere bir öğretmen tarafindan verilmesi gerektiğini ileri sürmüştür. Ona göre coğrafya, doğal ilişkileri anlamada yardımcı olurken tarih, insancıl bağlantı ve ilişkileri tanıma becerisi sağlayan yaşamın iki yüzüdür. Tarih dersi coğrafya dersiyle paralel gitmeli, öğretim sırasında harita kullanılmalıdır (Ata, 1998: 61-62). Olayın meydana geldiği coğrafyanın iyi tanınması, olayın daha iyi ve doğru kavranıp yorumlanmasını sağlar. Bunun sonucudur ki tarihî coğrafya diye bir kavram gelişmiştir. Tarihî coğrafyada coğrafyaya tarihin penceresinden bakılmaktadır. Genel itibarılya ezberci ve bundan dolayı da öğrenci için sıkıcı bir ders olarak kabul gören tarih dersi (Gardner, W. E.,Demirtaş, A., Doğanay, A., Çiçek, R., Güney, E. ve Kitapçı, Z., 1997: 1.11-1.14.) konuları, coğrafya yardımı ile daha somut ve görsel temeller üzerine oturtulmaktadır. Bu da öğrencilerde kalıcı öğrenme sağlamada etkili olabilir.

Tarih dersinin konularına bakıldığında toplumların yaşam şekilleri, ekonomisi, siyasî ve ekonomik faaliyetleri, uygarlığa katkıları hatta dünyayı algılamaları bulundukları coğrafya ile yakından ilgilidir. Bundan dolayı tarihin konuları içinde yer alan birçok uygarlık, coğrafi özellikler ve kavramlarla ifade edilmektedir. Örneğin Orta Asya Bozkır Uygarlığı ifadesi hem konumunun hem de iklimin uygarlık üzerindeki etkisini vurgulamaktadır. Karasal ilkimin hüküm sürdüğü bozkır toplumları tarihte daha savaşçı ve mücadeleci toplumlar olarak yer alır. Aynı şekilde dağlık bölgelerin insanları da mücadeleci ve savaşçıdırlar. Balkan ve Kafkas toplumların da olduğu gibi. Nehir kıyısında ve ovada verimli arazilerde yaşayan toplumlar ise genel itibarıyla tarım toplumlarıdır ve barışçıdır. Frigler, Lidyalılar buna güzel bir örnektir. Deniz kenarında kurulan uygarlıklar ise genel itibarıyla deniz ticaretinde ve kolonicilikte gelişmişlerdir. Ege uygarlıkları ve Akdeniz uygarlıkları gibi. Bundan dolayı bir tarihçi, tarihi bir olayı anlatırken, olayın geçtiği coğrafyayı mutlaka göz önünde bulundurmalıdır.

Aynı şekilde coğrafya bilimi ile özellikle de beşerî coğrafya ya da nüfus coğrafyası ile ilgilenen bir bilim adamı, çalıştğı 
alanla ilgili bir konuyu sağlam bir zemine oturtmak istiyorsa tarihten yararlanmalıdır. Örneğin nüfus ve göç olaylarında bölgenin tarihini bilmek son derece önemlidir. Nüfus azalması ya da artmasında bölgenin tarihsel geçmişini bilmek birçok şeyi anlamaya ve açıklamaya yardımcı olacaktır. Tarihteki salgın hastalıklar, savaşlar, göçler, doğal afetler ve benzeri olumlu veya olumsuz gelişmelerin beşerî coğrafyaya etkisi kaçınılmazdır.

Coğrafî yer isimlerinde, ismin nereden geldiğini ve anlamını tespit edebilmek için yine tarihe başvurabiliriz. Örneğin Oğuzların Anadolu'ya geldiklerinde hangi yolu izleyerek batyya doğru ilerlediklerini, geçtikleri yerlerdeki köy ve kasabalara verdikleri isimlerden anlayabiliriz. Bugün Çorum'un Bayat ve Dodurga ilçeleri Oğuz boy tablosunda yer alan isimlerdir. Anadolu'nun birçok yerinde Kayı, Oğuz, Kınık, Avşar (Afşar), Peçenek, Çepni, Bayındır, Iğdır vb. yer isimlerini görmek mümkündür. Yine aynı şekilde Arap coğrafyacılar tarafindan Farsça Deşt-i Kıpçak denilen Dinyester ile İrtiş Nehirleri arasındaki bozkır, Kıpçak Bozkırı olarak adlandırılmıştır. Çünkü X. yüzyılın sonu XI. yüzyılın başlarında Kıpçaklar, bu bölgeye gelip yerleşmişler ve 300 yıl kadar burada hakimiyet kurmuşlardır. Deşt-i Kıpçak için daha öceki dönemlerde Deşt-i Hazar ve Deşt-i Oğuz tanımları kullanıımıştır. Son olarak bu bölgeye Kıpçakların gelmesiyle bölge Deşt-i Kıpçak adını almıştı. Bu terim bölgenin Moğolların eline geçmesinden sonra birkaç yüzyıl daha bu adla anılmıştır (Kıldıroğlu, 2006: 161). Tüfek, Mikrop ve Çelik'in yazarı ünlü coğrafyacı Jared Diamond, Çöküş adlı eserinin Türkçe baskısı için yazdığı önsözünde, Türkiye ve Türklerin dünya tarihinde oynadığı rolden bahsederken, coğrafya üzerine vurgu yapmıştr. Asya ve Avrupa arasında bir köprü görevini üstlenen Türkiye'nin, medeniyetin gelişmesine olan katkısının yanı sıra çevre coğrafyalarla ilgili getirdiği çözümlerle dünyanın diğer ülkeleri için örnek teşkil ettiğini ifade etmiștir. Ayrıca Asya'dan Avrupa'nın ortalarına kadar ilerleyerek Avrupa ve Asya dil haritasını yeniden biçimlendirdiğine de dikkat çekmiştir (Diamond, 2006: 15).

Şer'iyye sicilleri, tapu tahrir defterleri, temettuat defterleri, nüfus defterleri, salnameler, seyahatnameler gibi birinci elden kaynaklardan, adı geçen bölgenin geçim kaynaklarını, hangi bitki ve hayvanların yetiştirildiğini, yer altı ve yer üstü kaynaklarını ve benzeri bilgileri elde edebiliriz. Bu bilgiler, yalnızca tarihçi için değil bölgenin araştırmasını yapan coğrafyacı için de son derece önemlidir.

Coğrafya Savaşmak İçindir adlı eserde coğrafyanın, tarihin de konusu olan siyasî ve askerî uygulamalar için stratejik bir bilgi olduğu vurgulanır. Buna göre devlet, egemenliği altnndaki insanları daha iyi denetlemek ve örgütlemek amacıyla bölgeler düzenler ve bunun için coğrafyadan yararlanır. Haritacılık da başlangıçta askerî amaçıı olarak savaşlar ve işgaller nedeniyle ortaya çıkmıştır (Lacoste, 1998: 12-13).

\section{Tarih Öğretiminde Kullanılan Birinci Elden Kaynakların Coğrafya Öğretiminde Kullanımı}

Tarih öğretiminde kullanılan birinci elden kaynakların birçoğu yine sosyal ve beşerî bilim olan coğrafya öğretiminde de kullanılabilir. Bunların bazılarına aşağıda değinilmiştir.

Nüfus Defterleri: Şehir ve kasabaların demografik, sosyal ve ekonomik yapısını anlamada nüfus verileri oldukça önemlidir. Her devlet takip edeceği siyaseti önceden belirlemek ve buna göre politika geliştirip gerekirse önlemler almak için hakim olduğu bölgelerde var olan ekonomik ve insan kaynaklarını tespit etme ihtiyacını duyar. Osmanlı nüfus istatistikleri de bu doğrultuda geliştirilmiştir. Sayımlar, arazi tetkikleri ve kalıcı bir nüfus kayıt sistemi, XIX. yüzyıl idaresi açısından son derece önem kazanmıştır. Nüfus kelimesi; Arapça "nefs" kelimesinin çoğuludur, şahıs, kişi anlamına gelmektedir (Devellioğlu, 1993: 1664). Osmanlı Devleti, hazineye gelir sağlama, savunma ve fetih için asker toplama gayesi ile arazi ve nüfus yazımı, sayımı yapılmasına ve bunlarla ilgili kayıtların tutulmasına özel bir önem vermiştir. Nüfus, bir ülkede veya bir bölgede belirli bir zamanda birlikte yaşayanların oluşturduğu toplam sayıdır. Nüfus, bir devletin en kıymetli sermayesi olup, iç ve dış politikayı belirleyen ve etkileyen unsurların başında gelir. Bağımsızlığını korumak ve milletler arası politikada rol almak isteyen her devletin elverişli bir coğrafi konuma, doğal kaynaklara ve belli bir sayı ve nitelikte nüfusa sahip olması gerekir. Devletler, coğrafyalarının büyüklüğü, nüfusunun yapısı ve dağılımı, komşu devletlerin nüfus potansiyeli ve kültür yapıları gibi hususları dikkate alarak nüfusunun büyüklüğü ve yapısal dağılımı ile ilgili değişmelerle etkileşim içinde olan konularda hedef belirleme ve bu hedeflere ulaşmak için gerekli mekanizmaları oluşturma şeklinde özetlenebilecek olan özgün nüfus politikaları geliştirirler (İpek, 2006, 347). Nüfus defterlerinde Divan $^{2}$ isimleri, divanlara bağlı köyler, köylerdeki hane sayısı ve hanedeki erkek nüfus ve bundan hareketle ortalama nüfus tespit edilebilir. Kişilerin fizikî özellikleri boy (uzun, orta ve kısa), sakal (kara, ak, kızıl, sarı, kır, köse vb.), bıyık (kara, sarı, kumral, az, gür, ter vb.) olarak belirtilmiştir. Aynı zamanda yaş, nüfus hareketleri, kullanılan isimler, özür grupları ve kullanılan lakaplarla ilgili bilgiler elde etmek mümkündür. Gayrimüslim nüfusun yer aldığı yerlerde ise bunlara ek olarak cizye mükellef özellikleri (alâ, evsat, edna) de yer almaktadır (Ünlü ve İskender Kılıç, 2014: 597-617). Nüfus defterleri, Beşerî coğrafya ve Nüfus coğrafyası çalışan araştırmacılar için önemli kaynaklardır.

2. Divan, tımar sistemi ile ilgili bir terimdir. XV ve XVII. yüzyıllarda belirli bir niyabet bölgesini ifade eden nahiyenin alt birimidir (Ünal, 2008, 52). 
Salnameler: Farsça yıl anlamına gelen sâl ile mektup, kitap anlamına gelen nâme kelimelerinden meydana gelmiştir. Türkçe yıllık kelimesi karşılığında kullanılmaktadır. Devlet tarafindan neşredildikleri için resmî belgelerdir. Geçmiş yıllardaki önemli olayları ve ait oldukları yılın müesseseleri, hâl tercümeleri, icraatları, istatistikleri, ticaret, sanayi, iktisat, tarım gibi bilgilerini kısaca veren eserlerdir (Bkz. Pakalın,1993: 105-106; İslam Ansiklopedisi, 1993: 134-136; Ünal, 2011: 588). Coğrafyaya kaynaklık açısından salnamelerde özellikle de vilayet salnamelerinde, bölgede meydana gelen ve halkı etkileyen sel, kıtlık, kuraklık, deprem, yangın vb. olaylar yer aldığı gibi bunların etkileri ve alınan tedbirler de yer alır. Ayrıca bölgenin geçim kaynakları, yeryüzü şekilleri, tarım ürünleri, hayvancılık gibi konulara da değinilir. Şehir coğrafyası, ekonomik coğrafya, tarihî coğrafya, sosyal ve kültürel coğrafya, siyasî coğrafya çalışan bilim adamları açısından oldukça değerlidir. Örneğin Trabzon Vilayet Salnamesinde, Samsun'un Çarşamba ilçesinin konumu ile ilgili şu bilgiler yer alır: “Canik Sancağı'na bağlı yerlerden biri olan Çarşamba kazası, Trabzon'un yüz kırk iki mil batısında ve Samsun'un doğusunda olup, Yeşilırmak Nehri'nin iki tarafinda düz bir zemin üzerine kurulmuştur" (Trabzon Vilayet Salnamesi. H. 1322 (1904-1905): 87). “Kuzeyinde Karadeniz, Doğusunda Terme Kazası, Güneydoğusunda Ünye Kazası, Güneyinde Erbaa Kazası ve Ladik Kazası, Batısında da Canik merkez ve Kavak Kazası ile çevrilidir. Çarşamba kazasının arazisi tamamıyla tortu araziden meydana gelmiş olduğundan oldukça düz ve deniz seviyesindedir. Bu geniş arazi üzerinde Yeşilırmak, Terme Irmağı ve Miliç Irmağı ile daha birçok dere ve çay, yataklarındaki meyil azlığından dolayı muntazam bir şekilde akmayıp, etrafa yayılarak çok büyük bataklıklar ve sazlıklar meydana getirmişlerdir" (Trabzon Vilayet Salnamesi. H. 1322 (1904-1905): 240). Yine iklimi ile ilgili olarak, “Çarşamba'nın etrafinda birçok göl ve bataklık olduğundan havası yaz mevsiminde tehlikeli bir durum alır. Diğer mevsimlerde ise gayet muntazam, olağan bir hale gelmektedir. Yaz mevsiminde kasabanın havasının iyi olmaması halkı yaylalara gitmeye mecbur etmektedir" (Trabzon Vilayet Salnamesi. H. 1322 (1904-1905): 165) bilgisine yer verilir. Bu havanın etkisi ise “Çarşamba ve Terme'nin bazı yerlerine iskân ettirilmiş olan bu muhacirlerin bir kısmı havanın kötü durumundan ve meydana getirdiği etkilerden dolayı hayatını kaybetmiş bir kısmı ise başka taraflara gitmişlerdir. Bu nedenle bazı köylerin yalnız harabeleri kalmıştır. Erkekler, kadınlara oranla bu kötü havadan daha çok etkilendikleri için zıraat da dahil bütün işler kadınlar tarafindan yapılmaktadır. Çarşamba ve Terme sahilinde yerli halkın bu kötü hava ve arazi şartlarının etkisinden dolayı karınları şişip dalakları bir tarafa doğru sarkmıştır. Halk fakirlikten ve hastalıktan kuvvetten düşmüştür. Çarşamba kazasının arazisi geniş ve oldukça verimli olduğu halde doldurulması ve ıslahı için çok fazla operasyon ve masraf gerektiren büyük bataklıklar sebebiyle çok az yararlanılmaktadır" (Trabzon Vilayet Salnamesi. H. 1322 (1904-1905): 240-241) şeklinde ifade edilmiştir. Ekonomik durumu ve bitki örtüsü ile ilgili olarak ise "Bütün bu bataklıklara rağmen bir ova olan Çarşamba arazi oldukça verimlidir. Arpa, buğday, çavdar, mısır darısı ve fasulyeden başka birçok sebze ve meyve yetiştirilmektedir. Arazide en fazla mısır üretilip, oldukça fazla miktarı da dışarıya gönderilmektedir. Kasabada ipek ve pamuktan bazı mensucat yapılmaktadır. Manda ve karasığır burada çok fazla yetiştirildiği gibi, güzel at ve kısraklar da yetiştirilmektedir. İnek, manda ve koyun sütünden birkaç çeşit peynir yapılır. Çarşamba'nın ihracatı arasında fasulye, keten tohumu, koyun ve hayvan derileri vardır" (Trabzon Vilayet Salnamesi, H. 1322 (1904-1905): 165-166).

Delta alanından sonra, güneye doğru giderek yükselen dağlık sahanın yükseltisi 1200 m.ye kadar çıkmaktadır. Bu sahanın üstü gür bir orman örtüsü ile kaplıdır. Kazada yer alan ormanlarda daha çok meşe, karaağaç, kestane, dişbudak, çam ve kavak ağaçları vardır. Her sene Tersane-i Amire için çıkarılan kestaneden başka tüccar tarafindan da büyük bir kısmı ihraç olunmaktadır. Çevresi genellikle sazlık ve bataklık olan göllerde sazan, iftina, alabalık ve kefal gibi çeşitli balıklar yaşar. Ufak bir gölde de oldukça çok kefal ve morina balığından yine çok miktarda yumurta ve havyar imal olunmaktadır" (Trabzon Vilayet Salnamesi, H. 1322 (1904-1905): 87) denilmektedir.

Seyahatnameler: Bir bölgenin ya da şehrin siyasî, idarî, ekonomik, sosyal ve kültürel özelliklerini seyyahların gözlemleri doğrultusunda kaleme aldıkları ve döneme ışık tutması açısından son derece önemli gezi notlarıdır. Kişilerin gözlemlerine dayanması nedeniyle iyi bir tenkit süzgecinden geçirildiğinde döneme ilişkin hemen her konuda önemli bilgilere ulaşmak mümkündür. Özellikle de bazı birinci elden kaynakların eksik olduğu veya hiç olmadığı durumlarda boşlukların tamamlanması açısından önemlidir. Çünkü sosyal ve kültürel hayata ilişkin resmî kaynaklarda yer almayan bazı bilgileri seyahatnamelerde bulmak mümkündür.

Tarih boyunca birçok seyyah ve onların kaleme almış oldukları seyahatnameler mevcuttur. Herodot ve Strabon, seyahatnamelerin ilk örneklerini vermişlerdir. Ancak zaman içerisinde seyahatnamelerin amaçları ve niteliklerinde önemli değişiklikler meydana gelmiştir. Seyahatnameler, tarih öğretimi açısından olduğu kadar coğrafya öğretimi açısından da önemli kaynaklardır. Çünkü seyyahın izlenimlerini aktardığı bölgenin veya şehrin fizikî yapısı hakkında bilgi verilirken yüzey şekilleri, yer altı ve yer üstü kaynakları, iklim ve bitki örtüsü, varsa kale veya limanı, ticarî faaliyetleri, mahalle ve sokakları hakkında bilgiler verilmektedir. Ayrıca gidilen yerin nüfusu, salgın hastalıklar, deprem, yangın, sel, kuraklık gibi doğal afetler ve bunların yol açtığı tahribatlar gibi sosyal yapı hakkında bilgiler de mevcuttur. Tarih boyunca birçok ünlü seyyah ve bunların kaleme almış oldukları seyahatnameler vardır. Bunların hepsine burada yer vermek mümkün değildir. Ancak Anadolu ve Türk coğrafyasını anlatan önemli seyyahlar ve eserleri ile ilgili belli başlıları şöyledir: Strabon, Roma döneminde bugünkü Amasya ili sınırları içinde doğmuş tarihçi, coğrafyacı ve filozoftur. Coğrafya (Geographika)

| Kastamonu Eğitim Dergisi, 27(2), 2019| 
adlı eseri, antik dünya ile ilgili bir coğrafya kitabıdır. Gezdiği yerlerle ilgili önemli bilgiler vermektedir. Doğmuş olduğu Amasya ile ilgili bilgi verirken “íçinden İris Nehri'nin aktığı geniş ve derin bir vadide kurulmuştur. İnsan emeği ve tabiat buraya hem şehir hem de kale karakterini sağlamıştır. Burası yüksek ve çok sarp bir kaya olup dimdik nehre doğru iner ve nehir tarafinda, şehrin kurulmuş olduğu yerde duvar şeklindedir ve iki tarafta da sivri tepelere doğru uzanan duvarlar vardır. Bu tepeler iki tane olup tabiî bir şekilde birbirlerine bağlıdırlar ve muhteşem birer kule halinde yükselmektedirler" (Strabon, 1969: 58) der.

İbn Battuta, ünlü seyahatnamesinde Türk ve Moğolların hakim olduğu coğrafyayı dolaşarak önemli bilgiler verir. Avrupa'yı dolaşmamıştır. Ortaçağın önemli seyyahlarındandır. Eserinde, gezmiş olduğu yerler hakkında özellikle de gittiği şehirlerle ilgili dikkat çekici bilgiler verir. Örneğin Antalya şehri ile ilgili olarak, şehrin gerek planı gerekse bakımı ile öteki ülkelerdeki benzerlerinden üstün olduğunu dile getirir. Şehir halkını ırk ve dinine göre ayrılarak faklı mahallelerde oturduklarını anlatır. Her birinin yerleşmiş olduğu mahalleleri tasvir eder. Şehrin etrafinın surla kuşatılmış olduğu bilgisini verir. Bağ ve bahçelerinin çok olduğu, Kamereddin adını verdikleri bir çeşit kayısının çok lezzetli olduğu gibi çekirdeğinin de tatlı olduğu ve kurutularak Mısır’a gönderildiğinden bahseder. Şehrin, sıcak yaz günlerinde bile buz gibi ve lezzetli gözelerinin (su kaynağı) meşhur olduğunu vurgular (ibn Batuta, 1971: 6-7).

Evliya Çelebi, XVII. yüzyılda Osmanlı topraklarında gezerek gördüklerini, Seyahatname adlı on ciltlik eserinde toplamıştır. Gittiği yerlerle ilgili oldukça ilginç bilgiler vermektedir. "Tokat şehri yedi-sekiz dere içindedir. Poyraz tarafi açık olduğu için havası güzeldir. Kışı mutedil olduğundan meyvesi boldur. Dört bir tarafindaki bostan ve bahçeler içinden akan sular cennet bahçesine benzeyen bahçelere su verir. Bu bahçelerdeki bülbüllerin ötüşü insan ruhuna ferahlık verir. Meyveleri sulu ve tatlıdır. Birkaç gün bekleseler de tatları bozulmaz. Şehirde soğuk ve tatlı sular vardır. Tozanlı, Kerenç, Eğerli, Kaya, Kiraz deresi, Aksu, Hıdırlık Irmağı, Alaca Mescid Tekkesi Suyu çok meşhurdur. Halkın çoğu bağcılık, çiftçilik ve sanatla uğraşır. Yedi çeşit buğdayı olur. İri taneli arpası, bakla ve mercimeği boldur. Tokat şehrinin altından akan nehre Tozanlı derler. Bu nehir Tokat'tan yukarıda ve Tokat dağlarından gelip, Tokat kalesi önünden geçerek eski İnepazarı'ndan beri Kadı Gölü’nden ve Turhal Kalesi kasabasının ardından geçip, Çengelli belden, sarı Kusundan, Duruykâri köprüsünden Ceylan köprüsünün ardından Çekirge Suyu’na karışır. Bu köprülerin ikisi de kargirdir. Buradan geçerek Ferhat boğazı yolu ile Amasya'ya uğrar. Amasya'dan aşağıda bu Tozanlı Nehri isim değiştirerek Çarşamba Suyu adını alır. Çarşamba kadılığına uğrayıp birçok şehir, köy ve tarlaları suladıktan sonra Karedeniz kenarında ve Samsun kalesi'nin doğu tarafinda denize dökülür. Tokat şehri dolaylarında Tozanlı'dan başka Kereniç, Eğer kayası pınarları, Kelas Deresi, Aksu, Hıdırlık Irmağı vardır. Bunların hepsi Tozanlı’ya karışır. Şehrin yapılarındaki güzellik ancak Halep şehrinde olabilir. Şehrin toprağının genişlikte ve uzunlukta yeryüzünde benzeri yok gibidir" (Evliya Çelebi, 1966: 42-43-44) der. Evliya Çelebi, Tokat kalesinden oldukça uzun bahseder. Ayrıca Tokat şehrinin idarecileri, camileri, mescidleri, medreseleri, Darûl kurraları, tekkeleri, çeşmeleri, mahalleleri, ileri gelenlerinin sarayları, tüccar hanları, bedesten ve dükkânları, hamamları, akarsuları, iklimi, yapıları, kiliseleri, mesire yerleri, halkın dili gibi birçok özellikleri hakkında ayrıntılı bilgiler sunar.

Yine XVII. yüzyılda Osmanlı bilim adamı ve aydını olan Kâtip Çelebi'nin bir coğrafya ansiklopedisi olarak bilinen Cihannüma adlı eseri ünlüdür. Bu eser, özellikle tarihi coğrafya açısından önemlidir. Eserde, Osmanlı Devleti’nin yönetimi altındaki birçok ülke ve bölgenin tarihi ve genel coğrafyası dışında beşeri ve ekonomik coğrafyası hakkında da ayrıntılı bilgiler mevcuttur. Eser, daha sonra İbrahim Müteferrika tarafindan şekil, harita ve metin eklemeleri yapılarak basılmış$\operatorname{tr}$ (Elibüyük, 2009: 95, 96, 107)

Charles Texier, Küçük Asya: Coğrafyası, Tarihi ve Arkeolojisi adlı seyahatnamesinde, XIX. yüzyılda Osmanlı yönetimi altındaki Anadolu'da görülen ticarî faaliyetleri şu şekilde belirtir: Kerestecilik, dericilik, tütün üretimi, pamuk üretimi, tuz üretimi, tahıl üretimi, sebze-meyve yetiştiriciliği, afyon tarımı, ipekçilik, tekstil, halıcılık, dokumacılık, bakırcılık, tiftik üretimi, madencilik, hayvancılık ve şarapçılık. İzmir ve Ankara'daki tuz üretiminden bahseder ve bunun özel şahısların elinde bulunduğuna, devletin buralardan yalnızca öşür aldığına değinir. Aydın'ın pamuklu dokuma üretiminde, Bursa'nın ipekli dokuma üretiminde, Ankara'nın ise tiftik dokuma üretiminde öne çıktığını belirtir (Kaya, 2012: 250).

19. yüzyılda Karadeniz bölgesine gelen seyyahlardan biri olan John Macdonald Kinneir ise yaşamının büyük bir kısmını East India Company’nin askerî ve diplomatik hizmetinde geçirmiş asker kökenli bir gezgin ve diplomattır. 1800'lerin başında geldiği Samsunla ilgili olarak yeşil bitki örtüsüyle deniz arasında uzanan bir şehir olduğunu vurgular. Zeytin ağaçlarıyla çevrilmiş, yaklaşık 4 mil uzunluğunda bir körfezin bat ucunda kurulduğunu ifade eder. Şehrin Müslüman Samsun ve Kafir Samsun olarak ikiye ayrıdığını belirttikten sonra bunlarla ilgili olarak çeşitli bilgiler verir (Kuş, 2016: 233-234)

Henry John Van Lennep, 1870 yılında yayımlanan Travels in Little-Known Parts of Asia Minor adlı eserinde Tokat, Amasya ve Sivas bölgelerine ve Hitit devrine ait birçok arkeolojik kalınt hakkında önemli bilgiler bulunmaktadır. Lennep, Amasya ile ilgili olarak Tersakan Irmağı ve Yeşilırmak arasında kuzey kısmında zirveleri senenin büyük bir kısmı karla kaplı olan Akdağ’ın uzandığını belirtir. Kentin konumunun ve kentten geçen aynı zamanda sulama amacıyla da kul- 
lanılan çok sayıda ırmağın, şehrin iklimi üzerinde etkili olduğunu ifade eder. Buna göre, Amasya'da yazlar oldukça sıcak geçmektedir. Çünkü kalkerli kayaların geniş yüzeyi her yönden güneşi tüm kente yansıtmakta ve bu da sıcakları dayanılmaz hale getirmektedir. Bununla birlikte, kentin doğu ve bat kısmında bulunan yüksek kayaların, kenti güneşin yakıcı etkisinden her gün birkaç saatliğine koruma görevi gördüğünü söyler. Kış ayları ise Akdağ'dan gelen sert rüzgârlar ve iki vadi arasından gelen hava akımının birleşmesiyle oldukça soğuk geçmektedir (Kuş ve İskender Kılıç, 2015: 140-148).

Şer'iyye Sicilleri: Tarih bilimi açısından büyük öneme sahip bu kaynaklar, beşerî coğrafya, ekonomik coğrafya ve yerel coğrafya için de önemli bilgiler içermektedir. Şer'iyye sicilleri, bölgesel şer'i mahkemelerde kronolojik olarak tutulan birinci elden kaynaklardır. Bölgede yetişen ürünler, şehir ve kasabaların yaklaşık nüfusları, şiddetli soğuklar, çekirge saldırıları ve ürünler üzerine etkileri, sel, yangın ve depremler gibi doğal afetlerin bölgede neden olduğu ekonomik ve sosyal etkiler, bölgenin idari yapılanması, etnik ve dini yapı, meslekî ve sosyal statü, alınan vergiler, hangi hayvanların ve ürünlerin yetiştirildiği vb... birçok bilgi edinmek mümkündür. Örneğin, Kastamonu şer'iyye sicilinde, bu bölgeden toplanan adet-i ağnam vergisinden koyun-keçi gibi küçükbaş hayvancılığın yapıldığı, yaylak ve kışlak vergilerinden konar-göçerliğin olduğu ve sürülerin beslendiği görülür. Buğday, arpa, çeltik, soğan ve sarımsak öşürleri alınmıştır. Bunlardan arpa, Kastamonu kazasında hububat üretimi içinde birinci sıradadır. Daha çok kara arpa şeklinde geçmektedir. Bostan ve meyve öşürlerinden bunların üretiminin de yapıldığı anlaşılmaktadır. Misket elması ve Ergani eriği sicilde geçmektedir. Yine bu bölgeden bazı yerlerde nakit bazı yerlerde ise bal olarak alınan bal öşründen arıcılığın da yapıldığı anlaşılmaktadır (İskender, 2005: 572). Aynı şekilde alınan avarız vergisinden, ordu için gerekli olan erzak ve yemin temin edildiği, ama özellikle Kastamonu bölgesinden temin edilen katır ve kara kerç beygirinin bu bölgede önemli ölçüde yetiştiğini göz önüne sermektedir. Yine bu bölgeden donanma için asker ve özellikle çok sayıda kürekçi temin edilmesi bölgenin denizcilik açısında da önemli olduğunun ipuçlarını verir (İskender, 1994).

Tapu Tahrir Defterleri: Osmanlı Devleti'nde, yeni fethedilen ve tımar sistemi uygulanan topraklarda vergilendirilebilir ekonomik faaliyetlerin ve insan kaynaklarının tespiti maksadıyla, arazi ve nüfus sayımı yapılmaktaydı. Bu sayım sonuçları Tahrir adı verilen defterlere yazılır, ihtiyaç duyulması ve Padişahın değişmesiyle birlikte yenilenirdi (Çakar, 2003: 375-392). "Memleket Tahriri" adı da verilen ve modern nüfus sayımı niteliğinde olmayan bu tahrirlerle arazi kayıtları yanında, Devlet sınırları içinde her köy ve kasabadaki yetişkin erkek nüfus, ellerindeki toprak miktarı, tabi tutuldukları vergi mükellefiyetlerine dair rakamlar, mükelleflerin ve babalarının isimleri tek tek kaydedilirdi (Bingöl, 2004: 43-60). Örneğin Bitlis Sancağı tahrir defterinde Sancağın idarî taksimat, şehrin yaklaşık Müslim ve gayrimüslim nüfusu, yer alan aşiretler ve cemaatler (Altunay, 1996: 4-7); iktisadî yapıda toprak rejimi, çiftlikler ve mezralar, zirai üretim olarak hububat üretimi (buğday, darı, arpa), bağcılık ve hangi meyvelerin üretildiği, bağ, çayır ve yonca vergileri ve bal vergisinden ne gibi üretimlerin yapıldığı, hayvancılık ile ilgili bilgiler ve hangi hayvanların yetiştirildiği, alınan mukataalardan (boyahane, tabakhane, mumhane, ipek kapanı) ne gibi ticaret kollarının geliştiği bilgilerine ulaşılabilmektedir (Altunay, 1994).

Temettuat Defterleri: Bu defterlerde vergi mükellefi olan hane reisinin adı, baba adı, aile lakabı, fizikî özellikleri, mükellefin vergiye esas olan gelir kaynakları, kaynağın yıllık geliri yani taşınmaz malları, ekili olan ya da olmayan gelir getiren toprakları kaydetmektedir. Ayrıca ev, değirmen, kahvehane, gemi ortaklığı vb. ayrı ayrı tespit edilmiştir. Binek ve taşıma hayvanları, eti, sütü, yünü için beslenen hayvanlar tek tek yazılmıştır. Gayrimüslimler ve cizye vergileri de kaydedilmiştir (Çetin, 2009). Bunlar, hane esaslı olarak kaydedilmektedir.

Bu ana kaynakların dışında Osmanlı Devleti’nde Batılaşma hareketlerinin başladığı 1774'ten itibaren özellikle eğitim amaçlı Avrupa'ya gönderilen aydınların yaptığı çalışmalar ve gezi notları, bulundukları şehir ve yerlerin coğrafi özelliklerini belirten gözlemleri bilhassa şehir tarihçiliği açısından önemlidir. Hatta daha öncesinde Avrupa'ya giden bilim adamlarının özellikle Fransa'da gördükleri bina özellikleri ve çevre düzenlemeleri, Lale Devri olarak bilinen $1718-1730$ yılları arasında Osmanlı Devleti’nde meydana gelen sanat, mimari ve diğer alanlardaki gelişmelerde etkili olmuştur.

Yine Osmanlı arşivinde yer alan haritalar, plan-proje-krokiler, albüm ve fotoğraflar coğrafya çalışmalarında başvurulacak önemli ana kaynaklardır. Askerî ihtiyaçlardan doğmuş olan haritacılık çalışmalarına, 1800'lü yıllardan itibaren Osmanlıda önem verilmiştir.

\section{Tarihî Süreç İçinde Toplumların Davranışlarının Açıklanmasında ve Anlaşılmasında Coğrafî Unsurların Etkisi}

Tarihî olayların meydana gelmesinde, toplumların davranışlarının açıklanmasında ve anlaşılmasında coğrafî unsurların etkisi son derece önemlidir. Çünkü coğrafya yani devletin kurulup, toplumların yaşadığı yer siyasetine, ekonomisine, askerî faaliyetlerine, kültürel ve hatta dinî hayatnna etki etmektedir.

Jeopolitik, bir devletin kurulmuş olduğu coğrafyanın politikasına olan etkisidir. Örneğin antik Mısır’ı anlatırken “Kendine özgü bir uygarlıktı" denir. Bunun anlamı Mısır'da görülen bir takım gelişmelerin birebir dünyanın başka bir yerinde görülmemesidir. Çünkü Mısır, bulunduğu coğrafî konum itibarıyla o günün şartlarında dünyaya kapalı idi. Bir tarafı Akdeniz, diğer tarafı Kızıldeniz diğer iki tarafi ise çöl ile çevriliydi. Böyle olunca dünyaya kapalı kaldığı için gerek siyasal 
yapılanması, gerekse ordu teşkilat, sosyal yapısı, alfabesi, dini inancı tamamen kendine özgü idi.

Aynı şekilde Çin de kendine özgü bir uygarlıktır. Uzak Doğuda kurulmuş olan bu devlet, konumu itibarıyla ulaşımın ve haberleşmenin olmadığı eski çağda, diğer uygarlıklardan etkilenmediğinden devlet yönetimi, askerî teşkilat, mimarisi, toplumsal yapısı ve felsefî dinleri ile farklıık göstermektedir. Özellikle mimari yönden dünyada kendine özgü üç mimari vardır: Avrupa mimari tarzı, İslam mimarisi ve Çin mimarisidir.

Ancak bulunduğu coğrafî konumu itibarıly diğer toplumlarla etkileşim halinde olan devletler ve toplumlar etkileşim halinde bulunduğu bu devletlerin her birinden bir takım özellikler alarak daha gelişmiş bir kültür ve uygarlık meydana getirmişlerdir. Örneğin doğu ve batı arasında bir köprü olan Anadolu, buraya yerleşip devlet kurmuş olan her toplumdan bir özellik taşır. Aynı şekilde tarih boyunca bereketli toprakları nedeniyle birçok devlet tarafindan ele geçirilen ve sayısız uygarlığa beşiklik yapmış olan Mezopotamya da büyük bir kültür ve uygarlık birikimine sahiptir.

Anadolu uygarlıklarından olan Frigler, Sakarya Nehri kıvrımında kuruldukları için toprakları son derece bereketlidir. Bundan dolayı tarım toplumudurlar ve tanrıları da tabiat tanrıçası Kibele'dir. Çoğu tarım toplumunda olduğu gibi barışçıdırlar ve tabiattaki canlıları konuşturup ilk fabl örneği veren toplumdur. Oysaki Doğu Anadolu'da Van (Tuşpa) başkent olmak üzere kurulmuş olan Urartular, hayvancılıkla uğraşmışlardır. Taşın bol olduğu bu yerde tarımı geliştirmek için su kanalları yapmışlardır. Medler ve Asurlular gibi savaş̧ı toplumlarla komşu olan Urartular, savaş tanrısı Haldi'ye tapmışlardır. İyonlar, Fenikeliler ve Yunanlılar ise bulunmuş oldukları coğrafi konumlarııın dağlık olması ve deniz kenarında kurulmuş olmaları nedeniyle geçim kaynaklarını denizde arayan ünlü koloni devletleridir. Deniz yoluyla birçok toplumla iletişim halinde olduklarından kültür ve uygarlık taşımacılığı yapmışlardır.

Tarihçi ve filozof olan Montesquieu, Yunanistan'ın tarihini coğrafyasından okuduğunu dile getirmiştir. Çünkü coğrafya bir tasvir yapar. Ona göre, Atina'nın bulunduğu yarımadanın toprağının verimsizliği orada bir halk idaresinin kurulmasına, Sparta'nın bulunduğu Mora Yarımadası'nın toprağının verimliliği ise orada aristokratik bir idarenin kurulmasına neden olmuştur (Halkın, 1989: 40-41). Bunun tersi bir görüşle fizikî coğrafyanın aksine beşerî ve kültürel coğrafyanın toplumlar üzerinde daha etkili olduğunu savunan görüşler de mevcuttur. Buna göre bir toplum, toprağından gerektiği ölçüde yararlanamayabilir: Belçikalılar, Kongo'ya bazı bitkilerin ekimini sokmuşlardır. Ya da toplum, mevcut kaynaklarını çeşitli nedenlerle kullanmak istemeyebilir: Dini saygı gereği Hindistan'da halkın bir kısmının kutsal kabul ettiği ineklerden yararlanmaması gibi (Halkın, 1989: 42-43).

\section{Sonuç}

Günümüzde öğretim programları artık disiplinler arası bir yaklaşımla hazırlanmaktadır. Özellikle tarih eğitimi alanında, bütüncül anlayış doğrultusunda disiplinlerarası düzenlemeler hem önemli hem de gereklidir. Çünkü tarih konuları anlatıııken coğrafya, sosyoloji, ekonomi, felsefe, din, sanat vb. bir çok disiplin işin içine girmektedir. Tarih, bu bilim dallarıyla bütünleştirilmeden anlatılacak olursa kalıcı öğrenmenin gerçekleşmesi ve olayların mantığının kavranması oldukça güçleşecektir.

Lise tarih dersi kazanımları içerisinde yer alan mekânı algılama becerisi, tarihe yardımcı bilim dallarından coğrafya ile öğrenciye kazandırılmaktadır. Olayın geçtiği mekanı ve bu mekanın özelliklerini yani coğrafyayı anlamadan, tarih öğretilemez. Geçmişte meydana gelmiş olan tarihî bir olay haritalar, müzeler, mekan ziyaretleri ve çeşitli görsellikler ile daha somut hale getirilmektedir. Tarih derslerinde bununla ilgili olarak en sık kullanılan metaryal tarih haritalarıdır. Haritalardan yararlanırken yalnızca yer bilgileri verilmektedir. Ancak bu yeterli değildir. Günümüzde tarih öğretiminde, birçok yöntem, teknik ve yaklaşımlardan (Anlatım yöntemi, Soru-cevap yöntemi, Tartışma yöntemi, Gezi-gözlem yöntemi, Örnek Olay yöntemi, Beyin Temelli öğrenme, Çoklu Zekâ kuramı, Problem çözme yöntemi vb.) yararlanılmaktadır. Bunlardan yararlanırken en önemli unsur, başta öğretilecek konuların özelliğine göre daha sonra ise öğrenci ve öğretim ortamına göre bunların seçilmesidir. Her derste mutlaka her teknik kullanılacak diye bir şey söz konusu olamaz. Konuya uygun çeşitli yöntem, teknik ve stratejilerden yararlanırken, konuyla alakalı olarak coğrafyanın ilgili her alanından yararlanılabilir.

Her tarihî olay belli bir coğrafî mekânda meydana gelir. Tarihî olayların oluşumu esnasında iklim, yeryüzü şekilleri, konum vb. coğrafî faktörler etkilidir. Bu faktörlerin bilinmesi tarihî olayın tüm yönleriyle aydınlatılımasına büyük ölçüde katkı sağlamaktadır. Bu anlamda tarih ve coğrafya kardeş gibidir. Tarihin konuları içinde yer alan birçok uygarlık, coğrafî özellikler ve kavramlarla ifade edilmektedir. Aynı şekilde coğrafya bilimi ile özellikle de beşerî coğrafya ya da nüfus coğrafyası ile ilgilenen bir bilim adamı, çalıştğı alanla ilgili bir konuyu sağlam bir zemine oturtmak istiyorsa tarihten yararlanmalıdır. Örneğin nüfus ve göç olaylarında bölgenin tarihini bilmek son derece önemlidir. Nüfusun azalması ya da artmasında bölgenin tarihsel geçmişini bilmek birçok şeyi anlamaya ve açıklamaya yardımcı olacaktır. Tarihteki salgın hastalıklar, savaşlar, göçler, doğal afetler ve benzeri olumlu veya olumsuz gelişmelerin beşerî coğrafyaya etkisi kaçınımazdır. Coğrafî yer isimlerinde, ismin nereden geldiğini ve anlamını tespit edebilmek için vine tarihe bașvurulabilir.

| Kastamonu Eğitim Dergisi, 27(2), 2019| 
Tarih öğretiminde kullanılan birinci elden kaynakların birçoğu yine sosyal ve beşerî bilim olan coğrafya öğretiminde de kullanılabilir. Şer'iyye sicilleri, tapu tahrir defterleri, temettuat defterleri, nüfus defterleri, salnameler, seyahatnameler gibi birinci elden kaynaklardan, adı geçen bölgenin geçim kaynaklarını, hangi bitki ve hayvanların yetiştirildiğini, yer alt ve yer üstü kaynaklarını ve benzeri bilgileri elde edebiliriz. Şehir ve kasabaların demografik, sosyal ve ekonomik yapısını anlamada nüfus verileri oldukça önemlidir.

Sonuç olarak tarih derslerinde başta coğrafya olmak üzere tarihe yardımcı bilim dallarından yararlanılması, tarihî olayın somut hale gelmesine dolayısıyla öğrencilerde daha etkili öğrenmelerin sağlanmasına yardımcı olacağı gibi bu bilim dalların da tarih biliminin birinci elden kaynaklarından dolayısıyla da tarih biliminden yararlanarak çıkarımlarda bulunması daha isabetli sonuçlara ulaşılmasında etkili olacaktır.

\section{Kaynakça}

Altunay, E. (1994). 1540 (H. 947) Tarihli tahrir defterine göre Bitlis Sancağı (Yayımlanmamış Yüksek Lisans Tezi). Ondokuz Mayıs Üniversitesi/Sosyal Bilimler Enstitüsü, Samsun.

Altunay, E. (1996). 1540 (H. 947) Tarihli tahrir defterine göre Bitlis Sancă̆ı'nda yerleşme ve nüfus. Süleyman Demirel Üniversitesi Fen-Edebiyat Fakültesi Sosyal Bilimler Dergisi, 1(10), 1-10.

Arı, A. (2011). Bloom'un gözden geçirilmiş bilişsel alan taksonomisinin Türkiye'de ve uluslararası alanda kabul görme durumu. Kuram ve Uygulamada Eğitim Bilimleri, 11(2), 749-772.

Ata, B. (1998). John Dewey ve Türkiye'de ilköğretimde tarih öğretimi (1923-1930). Kocaeli Üniversitesi ve Atatürk Araştrrma Merkezi'nin ortaklaşa düzenledikleri "Atatürk'ün Cumhuriyet'in ilânından sonraki hedefleri” Sempozyum Bildiriler kitabı içinde (ss. 57- 77). İzmit: Atatürk Kültür, Dil ve Tarih Yüksek Kurumu Atatürk Araştırma Merkezi.

Atsız, N. (1997). Türk tarihinde meseleler. İstanbul: İran Yayımcılık.

Ayan, E. (2011). Türk tarihyazımının evriminde Annales kuramının yorumu. Tarih Okulu, (11), 75-101.

Bingöl, S. (2004). İstanbul'da 1829 nüfus sayımı ve bazı mahallelerin Müslüman nüfusu üzerine bir inceleme. Ankara Üniversitesi Dil ve Tarih-Coğrafya Fakültesi Tarih Bölümü Tarih Araşttrmaları Dergisi, 23(36), 43-60.

Boehm, R., Saxe D. W. ve Rutherford D. J. (2003). The best of both worlds: Blending history and geography in the K-12 curriculum. Washington: Gilbert M. Grosvenor Center for Geographic Education.

Cahen, C. (1972). İslam kaynaklarına göre Malazgirt Savaşı. Türkiyat Mecmuası. (Z. Kerman, Çev.), 17, 77-100.

Caine, R. N. ve Caine, G. (2002). Beyin temelli öğrenme. (C. Ülgen, Çev.) Ankara: Nobel Yayın Dağıı̆m.

Carr, E. H. (2003). Tarih nedir?. (M. G. Gürtürk, Çev.) İstanbul: iletişi̧m Yayınları.

Çakar, E. (2003). Tahrir defterlerine göre XVI. yüzyılda Humus şehri. Fırat Üniversitesi Sosyal Bilimler Dergisi, 13(2), 375-392.

Çakmak, M. A., Hamarat, E. (2016). Ipek Yolu tarihinin öğretiminde ABD merkezli bazı yaklaşımlar: Teknoloji, proje ve müze. Kastamonu Eğitim Dergisi, 24(1), 421-430.

Çetin, A. (2009). Kandıra Kaymas-Akçaova (Akâbâd) temettuat defterleri (1844-1845). i̇zmit: Kocaeli Valiliği il Özel İdaresi Yayınları.

Demircioğlu, i. H. (2006). Lise öğrencilerinin tarih dersinin amaçlarına yönelik görüşleri. Türk Eğitim Bilimleri Dergisi, 4(2), 153164.

Demircioğlu, i. H. (2007). Tarih öğretiminde öğrenci merkezli yaklaşımlar. Ankara: Anı Yayıncılık.

Demircioğlu i. H. ve Tokdemir, M. A. (2008). Değerlerin oluşturulma sürecinde tarih eğitimi: amaç, işlev ve içerik. Değerler Eğitimi Dergisi, 6(15), 69-88.

Devellioğlu, F. (1993). Nüfus. Osmanlıca-Türkçe Ansiklopedik Lügat. Ankara: Aydın Kitabevi.

Diamond, J. (2006). Çöküş. (E. Kıral, Çev.) İstanbul: Timaş Yayınları.

Diamond, J. (2010). Tüfek, mikrop ve çelik. (Ü. İnce, Çev) Ankara: Tübitak.

Dilek, D. (2002). Tarih derslerinde öğrenme ve düşünce gelişimi. Ankara: Pegem A Yayınları.

Elibüyük, M. (2009). Tarihi coğrafya bakımından önemli bir kaynak: Cihannüma. Coğrafi Bilimler Dergisi, 7(2), 93-109.

Evliya Çelebi (1966). Evliya Çelebi Seyahatnamesi. (Sadeleştiren: T. Temelkuran, N. Aktaş, M. Çevik), V- VI, İstanbul.

Gardner, W. E., Demirtaş, A., Doğanay, A., Çiçek, R., Güney, E. ve Kitapçı, Z. (1997). Sosyal bilimler öğretimi. Ankara: Milli Eğitimi Geliştirme Projesi Hizmet Öncesi Öğretmen Eğitimi.

Gümüşü, O. (2010). Tarihi coğrafya, İstanbul: Yeditepe Yayınevi.

Halkın, L. E. (1989). Tarih tenkidinin unsurları. (B. Yediyıldız, Çev) Ankara: Türk Tarih Kurumu Basımevi.

Herodotos (1983). Herodot tarihi. Çağının dünyasını anlatan ilk büyük kitabı. (M. Ökmen, Yunanca Aslıyla Karşılaştıran ve Sunan: A. Erhat) İstanbul: Nadir Kitap.

İbn Batuta Şemseddin Ebu Abdullah Muhammed et-Tanci (1971). ibn Batuta Seyahatnâmesi'nden seçmeler. (Hazırlayan: i. Parmaksızoğlu) İstanbul: Milli Eğitim Basımevi.

Ipek, N. (2006). İmparatorluktan ulus devlete göçler. Trabzon: Serander Yay. 
İskender, P. (1994). XVII. yüzyılın ikinci yarısında Kastamonu şer'iyye sicili, (Yayımlanmamış Yüksek Lisans Tezi). Ondokuz Mayıs Üniversitesi/Sosyal Bilimler Enstitüsü, Samsun.

İskender, P. (2005). Bir yerel tarih araştırması: 17. yüzyıl şer’iyye siciline göre Kastamonu. Gazi Üniversitesi Kastamonu Eğitim Dergisi, 13(2), 565-582.

İslam Ansiklopedisi (1993). Sâl-nâme. (c.10, ss.134-136). İstanbul: M.E.B. Basımevi.

Kafesoğlu, ì. (1964). Üniversite tarih öğretiminde yeni bir plan. ï̈ Edebiyat Fakültesi Tarih Dergisi, 19, 1-13.

Kaya, M. (2012). Charles Taxier'nin seyahatnamesine göre 19. yüzyılda Anadolu'nun sosyal, kültürel ve ekonomik durumu. Gazi Türkiyat Türkoloji Araştırmaları Dergisi, 10, 245-262.

Kıldıroğlu, M. (2006). IX-XVI. asırlarda Yenisey-irtiş bölgesinde Kırgız-Kıpçak ilişkileri. A.Ü. Türkiyat Araştırmaları Enstitüsü Dergisi, 30, 133-166.

Kodaman, B. (1997). Tarih araştırmalarında metod meselesi. Akademik Açı, 4, 1-8.

Kuş, A., İskender Kılıç, P. (2015). Henry John Van Lennep'e göre Amasya'nın fizikî ve coğrafî yapısı, II. Uluslararası Geçmişten Günümüze Merzifon ve Amasya Yöresi Sempozyumu bildiriler kitabı içinde (ss.140-148). Merzifon- Amasya: Edge Akademi Yayıncılık.

Kuş, A. (2016). Kinneir’ın Samsun-Tirebolu yol güzergâhındaki izlenimleri. M. Ç. Özdemir, Y. E. Tekinsoy (Ed.), Yabancı seyahatnamelerde Türkiye (ss. 231-253). Ankara: Türk Yurdu.

Küçükahmet, L. (2001). Öğretim ilke ve yöntemleri. Ankara: Nobel Yayın Dağıtım.

Kütükoğlu, M. S. (1990). Tarih araştırmalarında usul, İstanbul: İstanbul Üniversitesi Edebiyat Fakültesi Yayınları.

Lacoste, Y. (1998). Coğrafya savaşmak içindir. (A. Arayıcı, Çev.) İstanbul: Özne Yayınları.

Özçelik, i. (2001). Tarih araştırmalarında yöntem ve teknikler. Ankara: Gündüz Eğitim ve Yayıncılık.

Pakalın, M. Z. (1993). Osmanlı tarih deyimleri ve terimleri sözlüğü, III, (ss. 105-106). Ankara: M.E.B.

Strabon (1969). Coğrafya (Geographika). (A. Pekman, Çev.) XII (I-II-III), İstanbul: İstanbul Üniversitesi Yay.

Şengül Bircan, T., Safran, M. (2013). Tarih öğretiminde haritaların önemi ve kullanımı. Ahi Evran Üniversitesi Kırşehir Eğitim Fakültesi Dergisi (KEFAD), 14(2), 461-476.

Tekeli, İ. (2014). Coğrafya ve Mekân Üzerine. Bir disiplinin iç dünyası modern Türk coğrafyası üzerine söyleşiler. E. Bekaroğlu, A. R. Özdemir (Ed.), (ss. 3-4). İstanbul: İdil Yayıncılık.

Togan, Z. V. (1985). Tarihte usûl. İstanbul: Enderun Kitapevi.

Ünal, M. A. (2008). Osmanlı devrinde Sinop. Isparta: Fakülte Kitabevi.

Ünal, M. A. (2011). Salname. Osmanlı Tarih Sözlüğü, E. Ayyıldız (Ed.), İstanbul: Paradigma Yayıncılık, 588.

Ünlü, M., İskender Kılıç, P. (2014). Ayandon kazasının 1841 yılı nüfus yapısı, Turkish Studies, International Periodical For The Languages, Literature and History of Turkish or Turkic, 9(4), 597-617.

Yeğen, C. (2016). Annales okulu, Marc Bloch ve "Tarih savunusu: Veya tarihçilik mesleği” yapıt üzerinden Bloch'un tarih anlayışı, Abant Kültürel Araştirmalar Dergisi (AKAR), 1(1), 25-29.

Yıldırım, A., Şimşek, H. (2005). Sosyal bilimlerde nitel araştırma yöntemleri. (Gözden geçirilmiş 5. baskı). Ankara: Seçkin Yayınları. 